This article was originally published in History Compass, v. 6 no. 1, (2008), p. 207-242. The definitive version is available at www. blackwell-synergy.com http://www.blackwell-synergy.com/doi/full/10.1111/j.1478-0542.2007.00502.x

History Compass 6/1 (2008): 207-242, 10.1111/j.1478-0542.2007.00502.x

\title{
The Products of Consumption: Housework in Latin American Political Economies and Cultures
}

\author{
Marie Eileen Francois* \\ California State University Channel Islands
}

\begin{abstract}
Exploring links between housework and larger political economies and cultures, this article surveys discussions of paid and unpaid domestic labor in mostly urban settings in Latin American historiography. The focus is on inter-related questions: Who does housekeeping work? What is the nature of the work? What do those who do housework produce? Age, class, ethnicity, and gender intersect in housework, as it constructs identities drawn on specific cultural landscapes in diverse colonial and postcolonial settings. Bridging literature on unpaid work done in the home by wives, other female family members, and male and female slaves and literature on the paid work of domestic male and female servants of multiple ethnicities, this article argues that housework is not 'naturally' women's work, but has been constructed as such unevenly over time. The simultaneous legal, economic, and cultural subordination of women and non-whites under patriarchal colonial and liberal regimes that devalued housework - despite depending on it - left arduous, labor-intensive, skilled, and creative consumption work to these subordinated groups. This article also argues that while housework is part of social reproduction, it must also be understood as a productive process in multiple ways. While who did paid housework changed over time, wives and mothers did unpaid work continuously. The nature of the work changed with different contexts.

Consumption work produced tangibles such as tortillas, clean clothes, elegantly served tables, and wellturned-out individuals, as well as intangibles such as status, prejudice, gendered labor markets, and gendered politics.
\end{abstract}

Pounding out tortillas or manioc. Buying and selling tamales or pupusas outside a colonial tavern or through the window of a modern train. Rock-and-stream clothes washing, with laundry dried on bushes in the sun, or fountain washing and court-yard drying. Ironing and delivering freshly pressed blouses and suits. Washing dishes and polishing silver. Serving tables. Feeding babies. Developing personalities. Stroking egos. Tempering prejudice. Weaving social networks. Staging family rituals. Managing household accounts. Entertaining at home. Overseeing maids and cooks. These everyday, mundane, inconspicuous work activities might go unnoticed by onlookers and be taken for granted by consumers in colonial and postcolonial Latin America, as well as by those looking back. The products created through this labor are also often overlooked in stories of the past. ${ }^{1}$ Products of consumption are people and images and identities that result from the housekeeping work of consumption as well as 'stuff' consumed - i.e., goods and services. This work and the 'goods' produced were materially crucial to all classes of people and buttressed specific cultural, political, and economic hierarchies. Exploring links between housework and larger political economies and cultures, this article surveys discussions of paid and unpaid domestic labor in mostly urban settings in Latin American historiography. There are many questions asked and to ask about housework. ${ }^{2}$ Here I review old and new literature whose focus might be elsewhere for answers to inter-related questions: Who does housekeeping work where and when? What is the nature of the work itself? What do those who do housework produce? 
While its history remains difficult to investigate, housekeeping labor has been and is done every day to some extent by someone in or for every household anywhere in any time period. Feminist scholars Carol Pateman (examining European Enlightenment ideology justifying male dominance in society and in families) and Lourdes Arizpe (analyzing Mexican patriarchal norms in the twentieth century) write about the blurred line between housewives and servants under Western patriarchies. One similarity they find between housewives and servants is the work they do. ${ }^{3}$ The two groups doing the same work generally have been covered separately by historians, but will be taken up together here. There is not a literature exclusively of housework in Latin America, as there is for the United States. ${ }^{4}$ Instead, discussions about housekeeping in the past dwell in a number of places: histories of women, such as Silvia Arrom's classic on nineteenth-century Mexico and new work on the twentieth-century by Susan Besse on Brazil and Jocelyn Olcott on Mexico; studies of middle-class domestic and political life; work on slavery, such as Mary Karasch on Rio de Janeiro; histories of labor and industrialization, in Chile by Thomas Klubock and Elizabeth Hutchison and Costa Rica by Lara Putnam; and histories of children and family. ${ }^{5}$ A sizeable literature examines workers in other peoples' homes, as domestic servants or slaves. The classic is House and Street by Sandra Lauderdale Graham on nineteenth-century Rio de Janeiro. ${ }^{6}$ Servants are sometimes found in labor histories and histories of the middle or 'servant-employing class', but can be virtually invisible in both. ${ }^{7}$ With servants still prominent today in Latin America and the West generally, despite predictions of their demise with modernization, a substantial interdisciplinary literature continues to grow. ${ }^{8}$ Providers of commercialized housekeeping services - laundresses, seamstresses working from home, food vendors, boarding house owners - also get attention, joining a growing comparative literature on the 'commerce of domesticity' in largely 'female economies'.

In a concise distillation of theoretical and empirical approaches to paid domestic labor in Latin America and the United States, Heidi Tinsman in 1992 stated 'paid housework has been performed almost exclusively by women'. ${ }^{10}$ Research on paid housework in the colonial period and nineteenth centuries challenges this gendered assumption. Females certainly did housework in the past, especially unpaid work that mothers, wives, and daughters were obliged to do under patriarchy and in cities with high percentages of female-headed households. ${ }^{11}$ But male servants and slaves also did housework, a pattern well-established in comparative literature. By the twentieth century, Tinsman's observation rings true, and scholars have a number of answers as to why females have come to dominate domestic labor, paid and unpaid, in Latin America with non-white females concentrated in service. Not 'naturally' women's work, housework has been defined as such by patriarchal ideologies, cultural norms, and legal means. In naturalizing housework, colonial and capitalist patriarchal discourses made it invisible and devalued. Liberal separate spheres discourses assign household chores to family women as well as shape the labor market. Structural changes in the countryside push migrants into cities and gendered labor markets. The simultaneous legal, economic, and cultural subordination of women and non-whites under colonial and liberal regimes that devalued housework - despite depending on it - left arduous, labor-intensive, skilled, and creative consumption work to these subordinated groups.

Policy and legislation governing marital relations recognized economic and cultural values of good housekeeping even while assigning clear divisions of labor. The domestic labor of wives and their staffs was implicit in the gananciales marital regime in colonial Spanish America. In addition to real property or other material wealth she brought into her marriage, 'the wife assists [the husband] in economizing and watching over its formation and conservation'. ${ }^{12}$ Ideally, wives managed domestic economies with 'lo diario', money provided by husbands to purchase provisions to transform into consumable goods, as well as to 'keep a good house and clean clothes' for husband and family, with or without assistance from slaves and servants. In real life, wives might instead provide income as well as assume housekeeping responsibilities. ${ }^{13}$ Spanish Enlightenment reformers supported education for women that would 'prepare responsible 
mothers, thrifty housewives, and useful companions for men'. ${ }^{14}$ In Mexico City, eighteenthcentury Indian school girls were only taught washing and ironing skills along with rudimentary literacy, while elite girls studied academic subjects along with embroidery, religion, and art. Silvia Arrom points out that even wealthy women were trained in housekeeping skills so they could properly supervise servants. June Hahner describes the managerial work of slave-holding urban elite women in nineteenth-century Rio de Janeiro:

they supervised the production of clothing, food, domestic utensils, and other necessities of a largely self-sufficient household and were responsible for the family's health care, numerous religious obligations, and training of dependents. ${ }^{15}$

In the early twentieth century in Mexico, following a revolution that brought major changes to other aspects of life, the 1917 Law of Family Relations stated 'the management of and responsibility for household work shall be the concern of the wife', a legal allocation of housework until $1974 .^{16}$

Under colonial and nineteenth-century slave regimes, household labor was often divided amongst enslaved male and female workers, male and female servants, and family members. ${ }^{17}$ When there were no servants or house slaves, daily tasks fell to wives, daughters, and some sons. While servants generally received at least a nominal salary, slaves, wives, and children share a common characteristic - unremunerated labor. All these live-in housekeepers were 'rewarded' in in-kind ways - food, clothing, shelter, affection - the degree of which varied depending on status and location. ${ }^{18}$ Though wives were not themselves 'paid', Christine Hunefeldt notes the absence of a wife from a middle- or lower-class home in Peru meant 'an increase of family expenditures because somebody had to be hired to do the domestic chores'. ${ }^{19}$

Olcott points to conflicting understandings of housework in 1930 s post-revolutionary Yucatán, Mexico, where socialist and liberal theories and practices competed for allegiance. Some revolutionary men took issue with the statement in a survey that women were not 'factors of production in society', instead suggesting that 'women's child rearing, management of household budgets, and performance of "conjugal duties"' constituted production, arguing that 'especially the married woman, honorably fulfills the social law of labor'. In contrast, Olcott cites feminist organizers for whom 'women's reproductive labor remained invisible'. ${ }^{20}$ There has been enduring debate among activists and academics concerning the character of domestic labor, whether paid or unpaid - is it reproductive, or productive? In the 1970s, feminist scholars began engaging this question. Tinsman's 1992 article cited above provides a thorough overview of this literature. Heidi Hartmann and Esther Boserup in seminal pieces suggested housework's relationship to capitalism was an essentially economic one reproducing workers. ${ }^{21}$ Marxist feminist scholarship on Latin America still reflects this approach. ${ }^{22} \mathrm{New}$ work on status, identity, and consumption examining the relationship of housework to macro political economies places domestic labor in fuller cultural contexts. Not having to pay for social reproduction is not only vital to the advancement of colonialism and capitalism, but part of larger cultural hegemonic projects. ${ }^{23}$ Scholarship influenced by feminist scholars Joan Scott and Micaela di Leonardo, as well as cultural theorists Pierre Bourdieu, Michel de Certeau, Antonio Gramsci, and others examine the cultural value of paid and unpaid housekeeping work in terms of creating bourgeois identities, 'keeping up appearances', and just surviving for consumers of household services. It also illuminates the power relations and identities produced, reproduced, and contested during the process of consumption work. ${ }^{24}$ Productive housework is consumption work: goods such as food and clothing are produced - transformed from raw to finished states - to be consumed by household members; well-dressed, civilized personas are produced by laundering and nurturing which are then consumed by society at large. 
Regardless of who did the work and whether or not it was paid, then, the broad literature suggests that the work of consumption is both productive and reproductive. While usually not producing a living wage - the criteria for census takers and theorists who only counted remunerated work - the work of consumption produced people, goods, services, practices, images, status, etc., as well as reproduced the labor force for all levels of society. These 'products' were at once political, economic, and cultural. ${ }^{25}$

Studies of Asia and Africa broaden the vista on housework and its products that older emphases on Western approaches proffered. Ann Stoler and Karen Tranberg Hansen show domestic work done by male and female indigenous Indonesian and African servants, respectively, defining elite status and whiteness for Dutch and British colonists in the nineteenth and early twentieth centuries. ${ }^{26}$ This has parallel in the earlier Latin American colonial experiences, as shown for the seventeenth-century Andes by Ann Zulawski, but also in the twentieth and now twenty-first centuries when non-white female servants still serve white employers, as in the Bolivian story told by Lesley Gill. ${ }^{27}$ In multiple settings, household laborers, managers, and consumers were 'creators as well as the bearers of status' in emergent middle sectors. It was not only conspicuous consumption of luxury goods and of servant labor power that was important in Latin American political economies and cultures, but also mundane inconspicuous consumption of the products of consumption work such as daily meals, clean clothes, and nurturing vital to all classes and genders. ${ }^{28}$

As laid out in the following pages, who does housework, what the nature of the work underlying household consumption was, and what it produced changed over time in Latin America despite some enduring continuities. Married women and mothers have continually had to do the bulk of housework from colonial times to the present. While generally dominated by non-white women, the casts of servant and slave staffs cooking, cleaning, and serving in myriad other ways in households not wholly dependent on wives and other family women were particular to time and place, with slaves outnumbering servants in some seventeenth-century settings, more men than women in nineteenth-century Lima and Havana, and as many whites as non-whites in late nineteenth-century Argentina. The virtual disappearance of whites and males from domestic service in the region proves to be a relatively modern phenomenon. The persistence of domestic service as a major employment category into the twenty-first century in Latin America is remarkable, though now fewer live with their employers than in the past. Regarding the nature of the work, increasingly complex consumer economies and domesticity ideals transformed housekeeping expectations and standards after independence in the nineteenth century, and technological innovations brought gradual changes in the twentieth. While the person doing household labor and the nature of the labor depended on changing contexts, in all times and places consumption work continuously produced both tangible things like tortillas, clean clothes, elegantly served tables, and well-turned-out individuals, as well as intangibles such as status, prejudice, gendered labor markets, and gendered politics. The tangible and intangible products of housework changed with the context, and the degree to which those products of housekeeping created distinct cultures is an open question.

\section{Colonial Contexts for Housework and Who Did It}

With the vast majority of Latin Americans throughout history not materially well-off, in most households a patriarchal division of labor meant that wives, concubines, mothers, daughters, sisters, aunts, and grandmothers undertook the labor-intensive reproductive and productive housework, perhaps with one slave or servant, most likely before and after a shift of paid work somewhere else. Despite being ubiquitous, there is little in the literature detailing the infinite arduous, back-breaking tasks housework entailed, especially the further back in time we go. For Mesoamerica, domestic duties in indigenous society included 'five or six hours . . every day of the week' to shell, wash and soak, heat, wash again, grind and regrind corn on a stone metate 
into masa from which tortillas were formed and then baked on a griddle. This daily production of the staple food was extremely time consuming, onerous and gendered female, before and after conquest. ${ }^{29}$ We know that humble homes in colonial cities such as Mexico City, Lima, and Arequipa were concentrated in casas de vecindad, buildings with many one-room dwellings, and that 'much of the activity of daily life' such as laundering and cooking was accomplished in common courtyards. ${ }^{30}$ Without running water, laundering and housecleaning entailed carrying buckets filled at public fountains or streams through busy streets. The laundry itself might be done at the fountain and then carried wet back to the courtyard for hanging. The daily tasks of a solo housekeeper were many, done in increments or to a regular rhythm, with shopping, caregiving, and cleaning interspersed with the production of food and clothing. ${ }^{31}$

In colonial Latin America, housekeeping and consumption at a particular material level was a necessary part of the reputation and power of ruling elites. Elite subsistence, life style, and status depended on the work of largely non-white domestic staffs, male and female. The connection between the production of elite status and housekeepers goes back to the beginning of the Atlantic world. Charles Boxer reports on newly arrived Portuguese men in Saõ Tome in the early sixteenth century who acquired an African lavadeira (washerwoman) 'who acted as mistress and ran the household' ${ }^{32}$ In the sixteenth century, the compulsory make-up of ruling class households - the casas pobladas of Spanish America - included a hierarchy of domestic labor, with black slaves and Spanish and Indian servants supervised by white wives responsible for running what amounted to guest houses for royal authorities and transcontinental merchants. ${ }^{33}$ In Mexico City in the sixteenth century, more than 20 African slaves maintained 'great homes'. According to Lourdes Mondragón Barrios,

the Spanish ... women were adorned richly, accompanied in the streets and in their carriages by their slaves, who also wore beautiful clothing, as their livery was one more attribute reflecting the social position of the individuals [being attended]. ${ }^{34}$

Of course, the housekeeping work done by these household slaves encompassed more than parading fashion to enhance their owners' reputation. Men worked as cooks, carriage drivers, stable hands, and mayordomos (overseers), while slave women were assigned house and laundry cleaning tasks. Women also worked in child care, as amas de llaves (supervisory housekeepers), and cooks. Early colonial housekeeping staffs in Mexico City likely had more African slaves than indigenous servants, as the indigenous were freed from forced service in 1549. After 1650, the slave trade in New Spain was curtailed and slaves for domestic service harder to find due to competition from woolens obrajes and sugar estates, thus more Indians and mulattoes moved into positions as 'maid, coachman, or personal attendant' in the city. In the seventeenth century, arriving Spanish officials might bring with them male 'criados', some 'dons' with considerable social status themselves, reflecting Mediterranean practice. ${ }^{35}$

In Europe, class issues informed the utility of servant-holding to the production of status and superiority, and ethnicity was not a major factor. In colonial societies the world over where local indigenous and (in the Americas) imported African males and females and their locally born descendants served in European households, ethnicity, class, and caste intersected to produce status and superiority. ${ }^{36}$ The chief distinction between master/mistress and servant was ethnic on the northern frontier of New Spain, with the first socially constructed 'civilized whites' including Spaniards as well as 'whitened' castas who took honorific titles of 'don' and 'doña', and the second an indigenous 'other'. Susan Socolow suggests that Spanish women disappeared from more menial domestic service ranks by the seventeenth century, keeping supervisory positions in elite households, thus bolstering their employers' status. The 'more servile domestic chores' were increasingly performed throughout colonial Latin America by women of color, black and mulata in some places, Indian and mestiza in others. For Spanish South America, Jane Mangan finds mostly female - indigenous and African - servants in the highland silver boom town of Potosi in the late sixteenth century. ${ }^{37}$ In her study of domestic 
servants in coastal Lima in the early seventeenth century, Teresa Vergara Ormeño reports indigenous females dominating non-slave service, as men had a better chance of finding nonservice work in artisanry than did women. Service contracts attest to a hierarchy of servants, with white or whiter women amas de llaves who earned about 7 pesos a month, and the lowest positions of cleaning house and serving 'in whatever they are told to do' done by castas, indigenous (many of them immigrants from Chile) and slave women, with non-slaves earning a substantially lesser amount of 12 pesos a year. The pay included housing, food, medicine, Christian doctrine, and one cotton dress per year. Reflecting a half-century of imperial policy protecting the indigenous from forced labor, in 1609 the Real Audiencia de Santiago de Chile decreed that single Indian women who voluntarily wanted to work in domestic service could do so but only under a contract of not more than one year. Married indigenous women could work in household service with their husbands' permission. In the mid-seventeenth century, the slave population outnumbered Europeans and indigenous in Lima, and many slaves served in households. ${ }^{38}$ George Reid Andrews argues that

slave servants probably outnumbered free servants in slave ports such as Bahia, Rio de Janeiro, Buenos Aires, and Havana, and they were common even in cities further removed from the slave trade, such as La Paz and Quito. ${ }^{39}$

In highland Cuzco, in contrast, mestiza servants outnumbered slaves in convents and great homes of the seventeenth century, with lay sisters charged with chores 'such as cooking, nursing, and laundry', though servants and slaves, many of them children, were left the most arduous tasks. ${ }^{40}$

Servant contracts such as those used by Vergara Ormeño for colonial Lima are unusual in the rich detail they provide. Historians have limited sources to investigate domestic labor. Many turn to census data, as problematic as it is. Notorious for undercounting working women and children, censuses also suffer from questions of definition. ${ }^{41}$ How much in common do 'servants' counted in aggregate have? 'Servant' can include agricultural laborer, workshop assistant, and personal valet. Are people doing apprentice-like labor counted along with cooks and chambermaids? Are children of slaves and servants who do countless household chores counted? Are 'huerfanos' and 'agregadas' in manuscript census records mere residents in a household, or de facto servants? Are women listed as 'lavanderas' working only in the home where they are listed in manuscript census, or do they live there but launder clothes and linens for a number of households? When using aggregate numbers for later periods, how many laundresses work for themselves, and how many work in commercial laundries? Only late in the nineteenth century did some national censuses systematically count women as engaged in unremunerated housework. The works surveyed here collectively understand censuses as problematic representations of domestic labor workforces, most useful in suggesting the range of occupations (some of them quite skilled) associated with housework. Historians supplement census data with evidence from legal sources, institutional records, memoirs, and letters, as well as travel, proscriptive, and periodical literature, to approximate hopefully more closely the experience of houseworkers.

The domestic labor forces in Lima and Mexico City diverged in the late colonial period. By the early eighteenth century, the Spanish population had grown to constitute half of Lima's residents, while the combined mulatto and African population represented a third. At century's end, the presence of domestic slaves in Lima persisted alongside free servants, with no clear dominance of either males or females. Hunefeldt reports that the number of slaves in Lima continued to gradually decrease, from 25 percent of the population in 1792 to about 7 percent in $1845 .{ }^{42}$ How many freed slaves returned to households as servants, augmenting already high numbers of males in the free servant category from 1790? Socolow argues that in colonial domestic service by slaves there was a very 'gender-based task allocation'. Female slaves in 
households 'were overwhelmingly used to clean, wash, sew, and birth and tend children. . . Only the assignment of cook was given to either men or women'. It is not clear that Lima fit this pattern, with so many men in service. Socolow also notes that 'slave women far outnumbered slave men in the cities', which also was not the case for Lima at the end of the eighteenth century. ${ }^{43}$ Biology left wet-nursing to females, and in colonial Lima and elsewhere in Latin America it was largely slave and indigenous women who nursed infants. ${ }^{44}$ In contrast to Lima, in Mexico City the late colonial domestic force had very few African faces and was very female. At least 70 percent of those listed in domestic service occupations in the 1811 census were female. Of individuals in live-in service downtown, 50 percent were indigenous, 30 percent 'casta', and 20 percent 'español'. The 'casta' category includes mostly mestizos of mixed indigenous and European heritage, with a very small mulato/negro/pardo contingent evenly split by gender. Of indigenous and whites in service, most were female (72 percent and 82 percent respectively). Of mestizos(as), a majority was male (56 percent). ${ }^{45}$

More easily found in descriptive sources than census data, the work of children is a persistent characteristic of housekeeping labor from colonial times until the present. Hunefeldt tells how slave children were incorporated into the work regimen of households in nineteenthcentury Peru:

while the master's children grew up they would have companions who would play with them, then wait on them, and much later accompany them in their departure from their parent's house to begin this cycle anew. ${ }^{46}$

This process was not confined to the enslaved. Children of servants often became servants themselves in the same household once they were of a certain age. In seventeenth-century Lima, indigenous boys and girls of as young as eight lived as servants in Spanish households. Thomas Calvo suggests illegitimate children were prone to being put out to service, forced and unpaid, in seventeenth-century Guadalajara, while Ann Blum identifies children of single mothers as the most vulnerable in late nineteenth-century Mexico City. Children served in convents and other institutions, and institutions themselves served as employment agencies, training orphan and indigent girls in domestic arts and then placing them as servants in households, while boys were placed as apprentices. In the enclave plantation economies of early twentieth-century Central America, young indigenous males worked in households of engineers and managers as domestic servants hauling water and chopping wood. ${ }^{47}$

\section{Periodizing the 'Economy of Appearance' and Inconspicuous Consumption after Independence}

All these colonial slaves and servants, young and old, obviously produced food and clothing and kept houses clean, but these products of their labor often did more than allow their employers to subsist at an inconspicuous level of consumption. They fostered the production of status, prestige, and proper personas. Beatriz Ruiz Gaytán argues that after Mexico's independence from Spain, an 'economy of appearance' that had been the purview of colonial elites became a more generalized 'Mexican mode of living' among middle sectors seeking to acquire postcolonial prestige. The most important strategy in appearing 'decente' and of 'buenas costumbres' in the new era was to employ household servants. The same was true for Peru and Brazil and elsewhere after independence. Concerns about social position continued despite republican rhetoric, with national ruling classes of hombres de bien with similar needs of status maintenance to earlier Creole and peninsular power brokers, perhaps even an enhanced concern with appearance as the capitalist economy developed and fashions changed. Meeting the requirements of status included appearing properly turned-out in public, an aspect of daily life generally overseen by family females and their staffs through shopping for wardrobes as well as groceries, other housekeeping tasks such as laundry and ironing, and grooming family members for public presentation. ${ }^{48}$ In Brazil, where it did not involve a break with Portugal, 
independence was nonetheless a watershed in the periodization of the presentation function of housekeeping. Hahner finds evidence in traveler descriptions that after the Portuguese court arrived in 1808 ,

the intensification of commercial and political life ... required larger, more complex social gatherings and formal receptions in which upper-class women had to display proper social skills and graces in order to promote the family's position. ${ }^{49}$

There of course also would have been an intensification of work behind such display.

The work of consumption shifted in the late nineteenth century somewhat from making goods to purchasing them in the market place. Many goods used in household consumption that generated public display of status were still imported, though they increasingly came from England and France and then the United States. By 1920, Brazil, Argentina, and Mexico saw national industries substituting for imports in basic goods. Yet Bessie reminds us that many a wife and mother who found herself sewing clothes for the family 'carefully copied store-bought models in the hope that others would not recognize their clothing as homemade' ${ }^{50}$ Clothing, linens, and even furniture had to be cared for and properly displayed, not just purchased or made. Silver service had to be used and the latest fashions worn while entertaining with servants deploying the evidence of one's position. As Graham describes, presentation and consumption involved a lot of skilled work:

a meal meant a performance in which the serving maid presented unobtrusively both to family and to their guests her talents at waiting a table. On such an occasion she became the representative of the household. Serving assumed supreme confidence on the copeira who, before the audience of diners, first placed a steaming hot soup tureen, then received used plates and distributed clean ones, while not forgetting to place the head of the fish in one direction or the leg of lamb in another. After several courses and the carrying of weighty glass compote dishes together with other desserts, she offered coffee from a tray balanced gingerly on one arm while she poured, not overfilling the cups and adding just the right amount of sugar. If the smooth routine often broke into a noisy confusion of passing plates, waving flies away, supplying suddenly called for serving spoons, or ducking hot-tempered remonstrations, house servants nonetheless moved the meal through to completion. ${ }^{51}$

A growing separate spheres ideology that emerged as part of the liberal patriarchal discourse and culture in Mexico, Chile, Brazil, and elsewhere in the nineteenth century emphasized the cultural value of scientific and hygienic housekeeping, with institutional training in modern methods provided to wives, mothers, and daughters as well as orphans and servants, in order to maximize the utility of labor done in the purportedly private sphere. ${ }^{52}$ In Chile, the project of domestic training of working-class women and girls implicitly recognized the productive nature of housework - work which produced a more civilized, disciplined working man. This training might subvert the curriculum of schools supposedly dedicated to teaching industrial skills to girls to instead focus on 'preparing [poor] girls to be good housewives', as shown by Hutchison, or might be promoted by employers such as the Braden Copper Company studied by Klubock. ${ }^{53}$ By the twentieth century in Brazil, renewed emphasis on efficient scientific and financial management of daily inconspicuous consumption by housewives commingled contradictorily with the demand for elegant presentation at the more conspicuous level. ${ }^{54}$

A number of studies examine discourses surrounding modern motherhood, and the impossibility for lower-class working women to achieve domesticity ideals. ${ }^{55}$ Aside from childrearing, emotional work and kin work that motherhood in all classes entailed has not been systematically studied for Latin America. Besse identifies 'health care, socializing children, and organizing family and religious rituals' as part of the work of elite Brazilian women in the nineteenth century. ${ }^{56}$ More material chores of non-elite mothers and wives have gotten attention, and increasingly are being tied explicitly to larger political economies. Donna Guy reproduces a 
report by refomer Gabriela Coni, describing the day of a working woman in c.1900 Buenos Aires. To get to the factory by 6 a.m., 'if she is a mother and married, she arises at 4 or $4: 30$ to prepare breakfast, dress her children, and sweep and straighten out her lodging'. Home on her lunch break, 'she makes a fire, and prepares lunch for her family'. Home from the factory in the evening, 'She must begin the preparation of dinner, washing the dishes, and the children, if they need it. She must also mend, sew, iron, etc.' ${ }^{57}$ According to Heyman's study of Sonoran workers, housework necessarily involved 'caring for children, feeding workers, gathering gossip information, and otherwise making useful the hard cash or purchased commodities that workers bring in' ${ }^{58}$ In her study of United Fruit Company-dominated Costa Rica in the same years, Lara Putnam argues that full economic analysis must include 'food grown, bartered, or bought, and then carried, and prepared; water hauled for drinking and washing; trousers patched and dresses starched; and bush tea brewed so agues would pass' ${ }^{59}$ In Putnam's work, we find a rare reference to men doing their own housework in remote settlements tied to the enclave, though a vibrant 'cash service economy . . . squarely in women's hands' more often supplied clean clothes and hot meals for men without women at home to serve them. ${ }^{60}$ Who did the housekeeping for working women of little means? Hutchison offers a quote from a Chilean health inspector in 1922 suggesting it might go undone: 'She [a laundress] spends the whole day washing to help pay for the room and has not been able to tend to herself or her little room'. ${ }^{61}$ The workplace for domestic laborers, unpaid and on the market, in nineteenth- and early twentieth-century urban centers continued to be the courtyards of cramped cortiços (in Brazil), conventillos (in Chile and Argentina), and casas de vecindad. Photographs of women working over cook pots and laundering clothes in patios are reproduced in a number of studies. $^{62}$

Households of any class ensured the physical and cultural survival of its members, but also produced individuals ready for markets of economic, political, and cultural competition and suitable for consumption by public opinion and society. Women heading households, ranging from 24 to 45 percent of urban household heads in the eighteenth and nineteenth centuries, coped with a gendered labor market with lower wages for females than males and ideological contexts casting female employment as dishonorable and glorifying domestic roles. ${ }^{63}$ Female household heads had a harder time producing individuals who could compete in society, as portrayed in José de Alcencar's novel Senhora from the 1870s. Before coming into a fortune, Aurélia lived with her ill widowed mother and dull-witted clerk brother Emilio in Rio de Janeiro:

the full burden of the household fell upon Aurélia . . Domestic tasks, fewer in the home of the poor, yet nevertheless more demanding - laundry, bills from daily shopping, Emílio's accounts and other needs - took up part of her day; the rest she spent sewing.

Aurélia's suitor, Fernando Seixas was a low-level bureaucrat who squandered the savings of his widowed mother and jeopardized the future of two sisters so that he could 'project the image of a wealthy young man' and hopefully marry well. His mother and sisters worked to produce an individual with status and prospects. When renting out their slaves brought insufficient income, mother and daughters took in sewing and ironing to supplement subsistence and the conspicuous consumption of the only son. ${ }^{64}$ Mexican nineteenth-century writers such as Rafael Delgado also featured the role of females in the family producing men for public life through consumption work. Sometimes the image put forth on the street - the body admirably attired in the latest fashions - belied a poorer reality at home, the appearance of wealth a deliberate illusion produced by careful management of limited resources. ${ }^{65}$

\section{Men and Women Served: Demography of Late Nineteenth-Century Domestic Service}

While liberalism emphasized female roles of wife and mother and by the end of the nineteenth century promoted acquiring 'technical knowledge' to best fulfill those roles, women in emergent 
middle classes continued to turn to human technology to meet their responsibilities, just as the elite always had, relying on servants-of-all-trades as well as specialized servants such as cooks, laundresses, and valets when they could afford it. ${ }^{66}$ The gender and ethnicity of those in the statistics on the serving class show great diversity in Latin America after 1850, reflecting phenomena such as abolition, urbanization, and immigration. Judging by aggregate census data, in postcolonial Lima the domestic staffs became more male than female, 58 percent male by 1876. The statistical picture for Havana, Cuba from the 1890s also shows a majority of male domestic servants. ${ }^{67}$ As the numbers give no breakdown of what tasks these servants were doing, research needs to be done in alternative sources. With so many males in service in Lima and Havana, we cannot just assume that they are all cooks and coachmen. European history saw male servants in the majority in early modern settings, even doing the cleaning. Multiple studies of domestic service in colonial Africa reveal housekeeping gendered male in specific places in the nineteenth and twentieth centuries. In Northern Rhodesia, African nurse boys cared for British children and 'washboys' laundered and ironed linens; the retinue included kitchen boys, table boys for dining, house boys, water boys, etc. Many of these 'boys' were grown men. ${ }^{68}$ In British India, religion, caste and gender intersected in the division of household labor in European homes, with Muslim, Anglo-Indian, or upper-caste Brahmin men as butlers; male Muslim table waiters, tailors and scribes; and washermen, male nurses, and gardeners from lower castes associated with those tasks. Ayahs, or waiting women, were of lower castes. Cooks, male or female, were either low caste, untouchables, or Portuguese. ${ }^{69}$ While Pilar Gonzalbo notes in her study of everyday life in Latin America that 'the conservation and care of clothing has occupied the attention of women during many centuries', the comparative lens magnifies gendered divisions of household labor as social constructions in specific contexts, and not 'natural' givens. ${ }^{70}$

The transition found in Europe from male to female servant by the end of the eighteenth century was not transferred universally in real time across the Atlantic. In societies where African slavery persisted into the nineteenth century, such as Peru and Cuba, male and female faces in domestic service also persisted. That Brazil does not fit this model suggests other factors are in play, such as government policies channeling genders into specific sectors, or labor market opportunities shaped by discourses constructing certain jobs as men's or women's work. ${ }^{71}$ But cultural preference can trump the market: Hansen found that even during the postWWI era in Zambia when African men's labor power was critically needed in mines and other sectors, employers continued to insist on man servants in their homes and this legacy 'helped as the years went on to construe the gender division of labor in domestic service in terms that made African men better suited for it than women'. ${ }^{72}$

In the 1872 Brazilian census, females constituted 74 percent of slaves employed in household labor. Female slaves performed menial cleaning, fetching, and kitchen tasks, but some were also skilled cooks, seamstresses, laundresses, and nursemaids. Slaves even served as supervisory housekeepers and ladies-in-waiting to wealthy women. In Rio de Janeiro, as slavery ended in 1888, free black women dominated service, but immigrant white European women also occupied the ranks of housekeeping staffs, as was true in neighboring Argentina. While white servants were sought for prestige, Rio's servant-employing families preferred free black servants, who presumably were accustomed to the traditional control system and thus more 'obedient'. From 1873 through 1940, more than half the female work force was in domestic service in Rio, with over 80 percent of domestic service workers in Brazil female. ${ }^{73}$ In Jamaica, when abolition came fifty years sooner than in Brazil, females comprised about 70

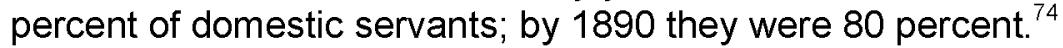

Argentina and Mexico are two places where slavery was abolished soon after independence, but their paths diverged as European immigration flowing to South America bypassed Mexico. The Mexican nobility at independence lived ostentatiously, with dozens of servants blending in with poor relations and orphans. By the mid-nineteenth century, four out of five household 
servants were locally born females, many of them indigenous and mestiza migrants from the countryside. ${ }^{75}$ While statistically a distinct minority, the English visitor Mrs Alec Tweedie was surprised at the number of male servants in Mexico City in 1900. Male or female, their remuneration was inadequate: 'domestics do not live luxuriously: they exist on tortillas and hot sauces, and generally sleep rolled up in a blanket on the floor'. ${ }^{76}$ Half the females employed in 1910 worked in domestic service, with females representing 80 percent of servants. It may be that for the Mexico City case, the status-motive for being a servant-employing family came to be replaced by a housewife-replacement motive. Professionals employed in private firms, a group more likely to include women who would therefore need replacements for housekeeping services at home, were more likely than government employees, a sector overwhelmingly male, to have paid domestic staffs. Generally, municipalities with the most people engaged in middle class occupations also had the largest number of domestic servants in $1910{ }^{77}$ The demography of domestic service in Chile resembles Mexico more than neighboring Peru, with migrant women dominating the sector in Santiago at the end of the nineteenth century. The census categories of cook, servant, and 'cleaner' were 80 percent female. In 1907, 73 percent of all employed females in Santiago were laundresses, seamstresses, or domestic servants. ${ }^{78}$

In stark contrast to other Latin American cities, Buenos Aires' domestic labor force was increasingly European. Judging by Alfredo E. Talles and Raúl Poczter's analysis of a sample of the 1855 census, the 'doméstico' population was very female (83 percent) and largely native to Argentina (66 percent), though a full third were foreign-born. Andrews suggests some 'natives' were Afro-Argentines, although after abolition the city faced a shortage of domestic servants, suggesting that freed blacks resisted the strong 'association with African descent and working as a servant'. ${ }^{79}$ Talles and Poczter find that more foreign-born servants were male (29 percent) than were Argentine-born servants (11 percent). The majority of foreign-born in Argentina were Italian, French, or Spanish (in that order), with fewer English, Irish and Scottish as well as Germans, Portuguese, Swiss, and Austrians (in that order). By 1900 in prestigious neighborhoods of Buenos Aires, households studied by Isabel Laura Cárdenas had numerous servants on staff, and they were a multi-cultural lot. The many servants who were European immigrants were as likely to be male as female. As competition between blacks and increasing numbers of immigrants in the labor market limited opportunities for Afro-Argentines, black men and women again became prevalent in domestic service. An old mark of colonial prestige was modernized, as it was 'chic to employ retinues of well-dressed black servants', with the 'elegantly-turned out manservant' a regular in fiction and cartoons. ${ }^{80}$

\section{Housekeeping in the Twentieth Century}

Housework is of course a constant throughout history, and the degree to which it is performed by paid workers in Latin America is a remarkable continuity. Gill argues that wives of professionals, mining entrepreneurs, and large landowners in 1930s La Paz 'could not imagine running a household without servants because they had grown up with domestic workers attending to their every need'. Indeed, their genteel social position depended upon the presence of Aymara women doing their housekeeping. In later decades, those who could not afford a livein maid 'almost always hired a part-time laundress'. ${ }^{81}$ One way the domestic service labor structure has changed over time is that there are fewer live-in servants than live-out. For Chile, contemporary designations are 'puertas adentro' and 'puertas afuera'. ${ }^{82}$ Mary Goldsmith offers an excellent detailed breakdown of 'the productive process of domestic service' - involving detailed, labor-intensive, and time-consuming tasks of both live-in and day hires - based on informants in Mexico City in the 1980s. ${ }^{83}$ While domestic service is still an important employment category in Latin America, more of the work from the 1930s on is done by wives, mothers, sisters, daughters, aunts, etc. If there is no adult woman in the house, daughters 'did all that kind of women's work - cooking, cleaning, washing, ironing' ${ }^{84}$ Veccia's mill worker informants 
remember making 'virtually everything their families wore, from undergarments to the tailored shirts and fancy dresses that were carefully guarded for special occasions' in 1940s São Paulo. Married daughters returned to parents' houses to help with housework and nurse the sick or care for elderly relatives, grandmother's served as nannies, girls scrubbed pots and pans and ironed clothing, mother's rose well before daybreak to get fires going on coal stoves. ${ }^{85}$ Training in domesticity continued. Mexican Catholic Action chapters taught 'sewing, cooking and other "domestic arts" ' to working-class and peasant women in the 1930s. ${ }^{86}$ In São Paulo in the 1950s, Centers for Domestic Instruction offered 'courses for maezinhas (little mothers) aimed at nineto fourteen year- olds, the preparation-for-marriage courses aimed at young women, and all other courses open to anyone sixteen or older'. The curriculum included cooking, child care, household management, domestic hygiene, and sewing. The goal was for working-class wives to approximate as closely as possible the ideal middle-class household. ${ }^{87}$ Similarly, in the 1960 s, Colombian factory owners offered wives and daughters of workers (though not the female workers they employed) courses in embroidery, cooking and dressmaking. ${ }^{88}$

Gill points out differences between housekeeping in the modern era in the U.S./Europe and Latin America. In Bolivia, 'household workers played a key part in the elaboration of white, female domesticity because housekeeping was so time-consuming' in the 1970s, with no supermarkets or frozen foods or fast food restaurants available. Only the wealthiest La Paz homes had the range of appliances found in the United States. ${ }^{89}$ As supposedly labor-saving appliances such as vacuums or washing machines were adopted in middle- and upper-class homes since the 1970s, they were often not to lessen the work load of family women, but incorporated into the domestic servant's regimen. ${ }^{90}$ Servants have not always embraced this change eagerly. In the late nineteenth century Fanny Gooch described her consternation at her male and female servants' resistance to using the state-of-the-art American stove she had moved to her Saltillo, Mexico home at great expense. For a contemporary Hollywood example, the Guatemalan maid in the 1980s film El Norte preferred laying out her employer's clothing on the bushes to dry to using the clothes dryer, an act met with equal consternation by her white female employer. Higman argues that the washing machine brought laundry back into the Jamaican household, now the purview of a maid-of-all-work and no longer of independent washerwomen. ${ }^{91}$ Whether or not modern machinery has become part of servants' or housewives' daily routines, modern standards of cleanliness and efficiency increased work loads: 'mopping floors on a daily basis, ironing laundered underwear to kill lingering germs, and scouring bathrooms from floor to ceiling were part of the assigned tasks'. ${ }^{92}$

\section{Analyzing What Housework Produces}

To some extent, the role of housekeeping in producing people, goods, services, and identities is not bound to any particular economic, political, or cultural context. Every human needs to eat and to be clothed and to be sheltered. Indeed, common patterns in the role of housekeeping production emerge in the literature reviewed above from the colonial era through the recent past. But something Mrs Tweedie commented on a century ago needs further consideration. In her description of the lifestyle of servants in Mexico City, the tortilla appears as a basic necessity. The skilled work of making tortillas might be paid or unpaid. If a servant makes them, it is remunerated to some degree. If purchased from a tortillera down the street, labor value was set by the market of supply and demand and paid by the consumer. If a life partner or mother makes the tortillas consumed by her family, the work goes unpaid. As Mrs Tweedie reminds us, tortillas sustained servants, male and female, as well as the population at large. The point I want to make here, and it will be obvious to many, is that the tortilla is central to Mexican identity. Just try and deny a Mexican male tortillas for awhile. To a Peruvian being denied tortillas means nothing because tortillas are not meaningful. The tortilla is now a product of mechanization, from the corn crop to the stack in a plastic bag on the shelf at the grocery store. Up until 
mechanization, tortilla production was largely accomplished by female hands. In another culture or at another time it might have been male hands, but the 'Mexican' way is that women make tortillas which nourish a cultural identity and taste preferences shared by Mexicans generally. In the past, it was an indigenous identity shunned by colonial and postcolonial whites, then a mestizo, now a national 'Mexican' one. ${ }^{93}$ The tortilla is a Mexican product essential to housekeeping and consumption seemingly forever, and the consumption of tortillas is a building block in Mexican identity. Hence, it is not just that housekeeping produces food or people generally, but it produces culturally specific food and people. To what degree did housekeeping produce differentiated cultures in other ways, such as local clothing styles, or even local laundering methods?

Maintaining statuses and status goods tied to public personas produced individuals such as politicians and factory workers for political, economic, and cultural arenas. As famously portrayed for England in the film Mary Poppins and described for the Caribbean by Isis Duarte, domestic labor produced suffragettes in the twentieth century, as middle-class women freed from chores and responsibilities of home benefit from the cooking and laundering done by uniformed servants that launched them into public life. The Brazilian writer Pagu in the 1930s criticized anarchist women for being parasites, 'dependent on the exploitation of their maids for their freedom'. ${ }^{94}$ One example of a maid's domestic labor producing her own children for the marketplace is given by Besse:

'Risoleta', who began working as a maid at the age of eight, valued work and took great pride in being an excellent cook, even while she deeply resented the pitiful wages she earned, the sixteen-hour days, her lack of rights to paid vacation, days off, and social security, and the disrespect shown to her by her employers. Nevertheless, it was the income she made working as a maid - supplemented by taking in laundry and boarders after she was widowed during her second pregnancy - that allowed her to raise her two daughters. . . . who both graduated from secondary school with degrees in accounting. ${ }^{95}$

The products of housework are not always tangible. Having particular people do housework produced status for persons served. Multiple identities and stereotypes about those serving were produced in 'raced gender' contexts where housework was done by people of color and women. Servants and housewives were deemed honorable or not depending on how much of their work took them into 'dangerous' streets. Domestic servants suffered characterizations as dishonorable, dishonest, ignorant, and of inferior caste. ${ }^{96}$ Wet-nurses and laundresses had particularly unsavory reputations, tied to issues of sexuality, class, and ethnicity. In eighteenth century Lima, portrayals in the press of slave and indigenous wet-nurses as dangerous usurpers of motherly affection producing effeminate boys belied anxieties rooted in racial hierarchies that were simultaneously produced and challenged by household work relations. In Colombia in the early twentieth century, stereotypes labeled laundresses as sexually promiscuous. Laundresses' reputations were also tied to the fact that their work often took them into the streets to find water and to fetch dirty and deliver clean clothes, and the anxiety of their employers about what washerwomen necessarily knew about them due to the nature of their task. ${ }^{97}$ Ethnic identifications with a particular domestic labor occupation were not static. In Buenos Aires, washerwomen had been black until end of the nineteenth century, when 'hearty Italian women', as described by the local press, displaced them.$^{98}$ Michelle Johnson's study of servant advertisements from the 1920 s to 70 s in Jamaica suggest the contradictions of looking for servants of 'honorable character' when honor and service were pegged at opposite ends of the color line. It was not just their poor image but the poor treatment they received - 'the señoras put you down a lot' - that made alternatives like factory work attractive to Colombian servants. ${ }^{99}$ With a separate sphere ideology solidified, Veccia points out that a working-class wife's identity in twentieth-century São Paulo was 'intimately tied to the way she executed the domestic labor that was culturally defined as women's work'. According to John French and 
Daniel James, women themselves came to be 'defined from the outside as either a good or a bad housewife/woman'. Besse makes a similar point for married middle-class women in Brazil, with a media-promoted identity for wives that hinged on housekeeping skill. ${ }^{100}$

As Gonzalbo argues for the colonial period and others for the modern, another product of the gendered construction of housework, whether done by housewives or paid servants, is the limited opportunity for

women in the labor market at large which continues to obtain today. Hutchison's study of Chile suggests two points in this regard. First, because women have had to do the domestic work in their own homes, their entry into other work has been limited - they need jobs with flexible hours, and they have little time to learn new skills. Second, she reports that when women were employed in Santiago's factories, they were concentrated in lower-paying jobs that mirrored their experience in housework, 'related to sewing, ironing, washing, and packaging the products'. ${ }^{101}$ Susie Porter takes a different tack, and argues that the labor market structure itself, shaped by the legacy of gender restrictions in guilds, is why women working outside of the home in Mexico concentrated in cigarettes and clothing. For Porter, women did not extend domestic skills into industrial settings: 'seamstresses did not sew in sweatshops because they learned to sew from their mothers, but because they were not allowed to be shoemakers, steelworkers, bakers, or printers'. ${ }^{102}$

Intangible products of household labor can be seen in the political arena. Olcott shows that in the 1930s and 40s in Mexico, 'women's daily experience of arduous reproductive labor tasks shaped their priorities as activists and revolutionaries'. ${ }^{103}$ Political agendas pushing corn mill cooperatives run by women's leagues, cooking and laundry collectives, sewing cooperatives, day care centers, maternity clinics, and access to water reflected housework demands. Mexican women also organized into unions with 'unsalaried women, ironers, laundresses, cooks, tortilla makers, and petty saleswomen', unions which faced hostility from middle-class women's groups. ${ }^{104}$ In the mid-twentieth century in Argentina, Bolivia and Chile in the midst of social revolutions, housewives in tin mining and agricultural communities organized unions and committees. The revolution in Cuba produced a 1975 family code that mandated an equal division of household labor between male and female members of households, though patriarchal divisions of labor persist in practice. Since the 1960 s, domestic service has been a sector under organization throughout Latin America. Domestic workers, paid and unpaid, recognize their productive role in capitalist society, and have engaged liberalism as political actors through unionization and association. ${ }^{105}$ Historians are now recognizing the productiveness of housework, too.

\section{Concluding Thoughts}

The productive housekeeping in colonial and post-colonial Latin America was done by a varied lot in terms of gender, ethnicity, and slave or free status, depending on time and place. Individuals are not ready-made. Status and respectable images did not come from thin air, but rather were made of whole cloth woven by the presence and work of people of particular genders and ethnicities. The work of slaves, maids, house boys, seamstresses, laundresses, valets, housewives, aunts, and daughters produced the polished, presentable, employable, and authoritative individuals that engaged in governance and economic enterprises in Latin America. The fact that someone else did the sewing, laundry, and table serving was one factor in the images that housework in elite and middle-class households produced. Hierarchies of domestic service mirrored and produced racial, gender, and class distinctions in society. Within household consumption work regimens, less strenuous and more independent jobs were most often held by whiter servants, male and female.

The concept 'products of consumption' in the title of this article has multiple meanings as the historiography shows the material world connecting households to society in different ways. 
Work done at home produced tangible goods - tortillas, carne asada, clean clothes - consumed within the home, with no conversion into commodity. The same goods might be produced in the home or in another service arena for the market. Food and nurture reproduced people of all ranks: slaves, artisans, factory workers, servants, professionals, elites. Products of consumption include cleanliness, domesticity, civility, servility, affection, dependency, hierarchy, prejudice, food preferences - in a word, culture. ${ }^{106}$ It is easiest to see housekeeping as productive when households were self-sufficient units producing most of what was consumed within. With the growth of commercial economies and the impact of industrialization, fewer 'goods' were produced at home, though this function never disappeared altogether, as the costs of factorymade clothing and food was beyond reach for many. Intangible products of housework continued through changes in political economy. A continuity from the colonial period is status as a product of consumption. There is also change regarding status, with the increased level of work needed for luxurious living as well as the prestige of having particular people doing that work at different times and places - whether African slaves, indigenous serving girls, Spanish amas de llaves, French valets, Irish nannies, or mulatta laundresses.

The connections between housekeeping, consumption, political economies, and culture of course continue. The recognition, especially by housekeepers, that they are active producers integral to these political economies and cultures is growing in Latin America - more so than in the United States or Europe. In the late twentieth century, domestic service continued to employ more women than any other sector, and is now a virtually female sector, even in Lima, where migrants and non-whites are concentrated. ${ }^{107}$ Girls continue to be channeled into domestic service, perhaps given over as young as six to employers as supposed godchildren by a contract that binds them until adulthood. ${ }^{108}$ Housekeeping is now seen as exclusively the domain of women, done by 'housewives' and hired help with few alternatives, both groups female, the latter often of color who then scramble to cover their own housekeeping. Women with means continue to leave most housework to paid help, while daughters share unpaid work with mothers. That this situation seems 'natural' represents a double victory for patriarchy and racism.

\section{Acknowledgment}

I thank Juan Rodrígez Buendía for research assistance, the interlibrary loan staffs at Auburn and Channel Islands for cheerful and prompt service, and the Auburn University College of Liberal Arts Humanities Development Fund and the CSU Channel Islands Office of Faculty Development Mini-Grant Program for research funding.

\section{Short Biography}

Marie Eileen Francois's publications include the book A Culture of Everyday Credit: Housekeeping, Pawnbroking, and Governance in Mexico City, 1750-1920 (University of Nebraska Press, 2006) and 'Cloth and Silver: Pawning and Material Life in Mexico City at the Turn of the Nineteenth Century', The Americas, 60/3 (January 2004): 325-62, winner of Tibesar Prize from the Conference on Latin American History. She has also published in Mexico: 'Vivir de prestado. El empeño en la ciudad de México', in Anne Staples (ed.), Bienes y Vivencias. El Siglo XIX Mexicano, Vol. 4, Historia de la vida cotidiana en México (El Colegio de México/Fondo de Cultura Económica, 2005) and 'Prendas and Pulperías: The Fabric of the Neighborhood Credit Business in Mexico City, 1780s-1830s', Estudios de Historia Novohispana, 20 (1999): 67-110. After eight years teaching in the history department and women's studies program at Auburn University, in 2006 she joined California State University Channel Islands as an Associate Professor of History. She is thankful for an Auburn University Humanities Grant and a CSUCI Faculty Development Mini-Grant for supporting her on-going comparative research project for a book on housekeeping in the Americas in the eighteenth and nineteenth centuries. 
She holds a B.A. in History and Latin American Studies from the University of Virginia, an M.A. in Comparative History from the University of California Santa Cruz, and a Ph.D. in Latin American History from the University of Arizona.

\section{Notes}

* Correspondence address: California State University Channel Islands, One University Drive, Camarillo, California $93012-$ 8599, United States. E-mail: marie.francois@csuci.edu.

${ }^{1}$ As a variety of terms and expressions for these efforts are used in the literature, I use labor and work largely as synonyms - housework and household labor, housekeeping work and housekeeping labor, domestic labor and domestic work, reproductive work and reproductive labor. David McCreery makes a distinction between labor and work, because 'labor' implies a level of political organization of workers. D. J. McCreery, The Sweat of Their Brow: A History of Work in Latin America (Armonk, N.Y.: M.E. Sharpe, 2000), 3.

${ }^{2}$ An enduring topic barely touched on in this essay is connections between sexuality and housework. See S. L. Graham, House and Street: The Domestic World of Servants and Masters in Nineteenth-Century Rio de Janeiro (Austin, TX: University of Texas, 1988); L. Putnam, The Company They Kept: Migrants and the Politics of Gender in Caribbean Costa Rica, 1870-1960 (Chapel Hill, NC: University of North Carolina, 2002); H. Tinsman, 'Household Patrones: Wife-Beating and Sexual Control in Rural Chile, 1964-1988', in J. French and D. James (eds.), The Gendered Worlds of Latin American Women Workers (Durham, NC: Duke University Press, 1997), 264-96. Other questions taken up by the literature include the relationship between housework and the larger labor market; the relationship between domestic service and migration and immigration; the power of discourse about domestic labor and who does it; the impact of low or no wages for housework; the nature of relations between servants and employers and household slaves and their owners; housework as a stage of development in a macroeconomic sense as well as in the lifecycle of an individual worker; housework as the source and/or result of patriarchal and racist oppression; and family life and culture of domestic servants.

${ }^{3}$ C. Pateman, The Sexual Contract (Stanford, CA: Stanford University Press, 1988), 125-30. Pateman also compares wives to slaves, focusing on legal positions, and not the work done. Arizpe illustrates how domestic labor is only sometimes formally recognized as work: 'Indeed, at the formal end of the spectrum, women servants who earn a salary are considered economically active and are included in the GNP; midway, women do the same tasks on an informal basis-part time and intermittently - and yet are paid for them without being considered economically active and without being included in the GNP; at the other end of the spectrum, housewives do full-time domestic work with no payment and are considered outside the economic system. All of these women obviously are doing exactly the same type of work. Thus there is a very real need to reconceptualize women's work'. L. Arizpe, 'Women in the Informal Labor Sector: The Case of Mexico City', Signs, 3 (Fall 1977): 36

${ }^{4}$ S. Strasser, Never Done: A History of American Housework (New York, NY: Pantheon Press, 1982); R. S. Cowan, More Work for Mother (New York, NY: Basic Books, 1983); J. Boydston, Home and Work: Housework, Wages, and the ldeology of Labor in the Early Republic (Oxford: Oxford University Press, 1993).

${ }^{5}$ S. Arrom, The Women of Mexico City, 1790-1857 (Stanford, CA: Stanford University Press, 1985); S. K. Besse, Restructuring Patriarchy: The Modernization of Gender Inequality in Brazil, 1914- 1940 (Chapel Hill, NC: University of North Carolina Press, 1996); J. Olcott, Revolutionary Women in Postrevolutionary Mexico (Durham, NC: Duke University Press, 2005); C. Hunefeldt, Liberalism in the Bedroom: Quarrelling Spouses in Nineteenth-Century Lima (University Park, PA: Pennsylvania State University Press, 2000); B. Owensby, Intimate Ironies: Modemity and the Making of Middle-Class Lives in Brazil (Stanford, CA: Stanford University Press, 1999); M. C. Karasch, Slave Life in Rio de Janeiro: 1808-1850 (Princeton, NJ: Princeton University Press, 1987); T. M. Klubock, Contested Communities: Class, Gender, and Politics in Chile's El Tentiente Copper Mine, 1904-1951 (Durham, NC: Duke University Press, 1996); E. Q. Hutchison, Labors Appropriate to Their Sex: Gender, Labor, and Politics in Urban Chile, 1900-1930 (Durham, NC: Duke University Press, 2001); Putnam, Company They Kept; A. Blum, Domestic Economies: Families, Work, and Welfare in Mexico City, 18841943 (Lincoln, NE: University of Nebraska Press, forthcoming).

${ }^{6}$ Graham, House and Street; L. Mondragón Barrios, Esclavos africanos en la Ciudad de México: El sevicio doméstico durante el siglo XVI (México: CONACULTA/INAH, 1999); T. Vergara Ormeño, 'Artesanos y Sirvientas: El papel de los hombres y las mujeres indígenas en la economía limeña (siglo XVII)', in N. Henríquez (ed.), El hechizo de las imágenes: estatus social, género y etnicidad en la historia peruana (Lima: Fondo Editorial de la Póntificia Universidad Católica del Perú, 2000), 33-54; I. L. Cárdenas, Ramona y el robot: el servicio domestico en barrios prestigios de Buenos Aires (1895-1985) (Buenos Aires: Ediciones Busqueda, 1986); A. S. Blum, 'Cleaning the Revolutionary Household: Domestic Servants and Public Welfare in Mexico City, 1900-1935', Journal of Women's History, 15/4 (2004): 67-90.

${ }^{7}$ A few of the essays in J. D. French and D. James (eds.), The Gendered Worlds of Latin American Women Workers analyze housework by wives and servants. Susie Porter does not include live-in domestic servants in her study of working women in Mexico City because she determines their employment to be of a private nature. S. Porter, Working Women in Mexico City: Public Discourses and Material Conditions, 1879-1930 (Tucson, AZ: University of Arizona Press, 2003), xxixxii. David McCreery's sweeping history of work devotes about 3 pages to domestic labor, even though 'fully one-half to 
two-thirds of all women in nineteenth-century Latin America who worked outside the home were servants'. McCreery, Sweat of Their Brow, 101. For 'servant-employing class' as a definition of middle class, see A. Rubio and M. Taussig, 'Up off Their Knees: Servanthood in Southwest Colombia', in Female Servants and Economic Development, Michigan Occasional Paper No. 1 (Fall 1978): 5-29. Servants are largely absent in both Hunefeldt's and Parker's otherwise close studies of middle class life in Peru. Hunefeldt, Liberalism in the Bedroom; D. S. Parker, The Idea of the Middle Class: White Collar Workers and Peruvian Society, 1900-1950 (University Park, PA: Pennsylvania State University Press, 1998).

${ }^{8}$ E. M. Chaney and M. Garcia Castro (eds.), Muchachas No More: Household Workers in Latin America and the Caribbean (Philadelphia, PA: Temple University Press, 1989); X. Bunster and E. M. Chaney, Sellers and Servants: Working Women in Lima Peru (New York, NY: Praeger Publishers, 1985); L. Gill, Precarious Dependencies: Gender, Class, and Domestic Service in Bolivia

(New York, NY: Columbia University, 1994); P. Hondagneu-Sotelo, Domestica: Immigrant Workers Cleaning and Caring in the Shadows of Affluence (Berkeley, CA: University of California Press, 2001); R. Salazar Parreñas, Servants of Globalization: Women, Migration, and Domestic Work (Stanford, CA: Stanford University Press, 2001); S. Radcliffe, 'Race and Domestic Service: Migration and Identity in Ecuador', in J. H. Momsen (ed.), Gender, Migration, and Domestic Service (London: Routledge, 1999), 83-97; L. M. Rivas, 'Invisible Labors: Caring for the Independent Person', in B. Ehrenreich and A. R. Hochschild (eds.), Global Woman: Nannies, Maids, and Sex Workers in the New Economy (New York, NY: Metropolitan Books, 2003), 70-84; N. Gregson and M. Lowe, Servicing the Middle Classes: Class, Gender and Waged Domestic Labor in Contemporary Britain (London: Routledge, 1994).

${ }^{9}$ L. Putnam, 'Work, Sex, and Power in a Central American Export Economy at the Turn of the Twentieth Century', in W. E. French and K. E. Bliss (eds.), Gender, Sexuality, and Power in Latin America Since Independence (Lanham, MD: Rowman and Littlefield, 2007), 133-62; Porter, Working Women; Bunster and Chaney, Sellers and Servants; Hutchison, Labors Appropriate to Their Sex; J. Mangan, Trading Roles: Gender, Ethnicity, and the Urban Economy in Colonial Potosi (Durham, NC: Duke University Press, 2005). Arizpe argues that in modern Mexico City, in times of economic need 'women turn domestic duties into economic activities by offering such services to other women. This represents an all-female supply and demand market'. Arizpe, 'Women in the Informal Labor Sector', 36. For the United States, Edith Sparks identifies 'commerce of domesticity' in laundry and boarding house businesses in San Francisco, while Wendy Gamber takes a 'female economy' approach to dressmaking. E. Sparks, Capital Intentions: Female Proprietors in San Francisco, 1850-1920 (Chapel Hill, NC: University of North Carolina Press, 2006); W. Gamber, The Female Economy: The Millinery and Dressmaking Trades, 1860-1930 (Urbana, IL: University of Illinois Press, 1997).

${ }^{10} \mathrm{H}$. Tinsman, 'The Indispensable Services of Sisters: Considering Domestic Service in the United States and Latin American Studies', Journal of Women's History, 4/1 (Spring 1992): 55. For an overview of the long history of domestic service in the West, including when and where males or females dominated, and recent historiography, see D. Romano, Housecraft and Statecraft: Domestic Service in Rennaisance Venice, 1400-1600 (Baltimore, MD: Johns Hopkins University Press, 1996), xv-xxvi.

${ }^{11}$ Pateman, Sexual Contract.

${ }^{12}$ C. D. Deere and M. Leon, 'Liberalism and Married Women's Property Rights in Nineteenth-Century Latin America', Hispanic American Historical Review, 85/4 (2005): 627-78

${ }^{13} \mathrm{~S}$. Lipsett-Rivera, 'Marriage and Family Relations in Mexico during the Transition from Colony to Nation', in V. M. UribeUran (ed.), State and Society in Spanish America during the Age of Revolution (Wilmington: Scholarly Resources, 2001), 126-27; S. C. Chambers, From Subjects to Citizens: Honor, Gender, and Politics in Arequipa, Peru, 1780-1854 (University Park, PA: Pennsylvania State Press, 1999), 102.

${ }^{14}$ Arrom, Women of Mexico City, 16; S. M. Socolow, The Women of Colonial Latin America (Cambridge: Cambridge University Press, 2000), 165-72.

15 J. Hahner, Emancipating the Female Sex: The Struggle for Women's Rights in Brazil, 1850-1940 (Durham, NC: Duke University Press, 1990), 5-6.

${ }^{16}$ A. Varley, 'Women and the Home in Mexican Family Law', in E. Dore and M. Molyneaux (eds.), Hidden Histories of Gender and the State in Latin America (Durham, NC: Duke University, 2000), 242.

${ }^{17}$ Some household slaves and servants were able to earn money for themselves and their masters/employers in city streets and markets, selling goods and services, blurring personal and entrepreneurial service. Graham, House and Street; M. O. Silva Dias, Power and Everyday Life: The Lives of Working Women in Nineteenth-Century Brazil (New Brunswick, NJ: Rutgers University Press, 1995); F. V. Matos Rodriguez, 'Quien Trabajara? Trabajo domestico, esclavitud urbana, y abolicion en San Juan en el siglo xix', Revista de Ciencias Sociales, 4 (1998): 219-45; C. Hunefeldt, Paying the Price of Freedom: Family and Labor Among Lima's Slaves, 1800-1854 (Berkeley, CA: University of California Press, 1994). Karasch, Slave Life; Hahner, Emancipating the Female Sex.

${ }^{18}$ Socolow, Women, 116-18. 
${ }^{19}$ Hunefeldt, Liberalism in the Bedroom, 161. For comparison of and blurry distinction between wives and servants, see Pateman, Sexual Contract, 125-30.

${ }^{20}$ Olcott, Revolutionary Women, 29-30.

${ }^{21}$ H. Hartmann, 'Capitalism, Patriarchy and Job Segregation by Sex', Signs, 1/3 (1976): 17-69; E. Boserup, Women's Role in Economic Development (New York, NY: St Martin's Press, 1970). See also J. W. Scott, The Politics of Gender in History (New York, NY: Columbia University Press, 1988); L. Balbo, 'The Servicing Work of Women and the Capitalist State', Political Power and Social Theory, 3 (1982): 251-70; R. Rapp, 'Family and Class in Contemporary America', in B. Thorne and M. Yalom (eds.), Rethinking the Family: Some Feminist Questions (New York, NY: Longman, 1982), 47-70; E. Boris, 'The Home as Workplace: Deconstructing Dichotomies', International Review of Social History, 39 (1994): 415-28; L. Fortunati, The Arcane of Reproduction; Housework, Prostitution, Labor and Capital, trans. H. Creek (New York, NY: Autonomedia, 1995). For analytic reviews of the theory, see A. Farnsworth-Alvear, Dulcinea in the Factory: Myths, Morals, Men, and Women in Colombia's Industrial Experiment, 1905-1960 (Durham, NC: Duke University Press, 2000), 24-35; Tinsman, 'Indispensable Services'.

${ }^{22}$ For recent discussions of Latin America, see E. Jelin (ed.), Family, Household and Gender Relations in Latin America (London: Kegan Paul International, UNESCO, 1991); Tinsman, 'Indispensable Services'; O. de Oliveira (ed.), Trabajo, poder, y sexualidad (México: El Colegio de México, 1989).

${ }^{23}$ Indeed, recent scholarship argues that it was Adam Smith in the eighteenth century that put forth the idea that those doing housework were 'understood to perform work that was not work', an idea picked up by Marx. Thus, the invisibility of the work that went into creating the Enlightenment's 'individual' became a cornerstone of liberal capitalist hegemony. C. Steedman, 'The Servant's Labour: The Business of Life, England, 1760-1820', Social History 29/1 (February 2004): 1-29. See also Pateman, Sexual Contract.

24 J. Scott, 'Gender: A Useful Category of Analysis', American Historical Review, 91/5 (1986): 1053-75; P. Bourdieu, Distinction: A Social Critique of the Judgment of Taste, trans. R. Nice (Cambridge, MA: Harvard University Press, 1984); P. Bourdieu, Language and Symbolic Power (Cambridge: Cambridge University Press, 1991); M. de Certeau, The Practice of Everyday Life, trans. Steven F. Rendall (Berkeley, CA: University of California Press, 1984), 39-40; A. Gramsci, Selections from The Prison Notebooks (New York, NY: International Publishers, 1971); M. di Leonardo, 'Introduction: Gender, Culture, and Political Economy: Feminist Anthropology in the Postmodern Era, in M. di Leonardo (ed.), Gender at the Crossroads of Knowledge: Feminist Anthropology in the Postmodern Era (Berkeley, CA: University of California Press, 1991), 1-48. Latin American historiography influenced by these theorists include Besse, Restructuring Patriarchy; Owensby, Intimate Ironies; Farnsworth-Alvear, Dulcinea in the Factory; Putnam, Company They Kept; Putnam, 'Work, Sex, and Power'; M. E. Francois, A Culture of Everyday Credit: Housekeeping, Pawnbroking, and Governance in Mexico City, 1750-1920 (Lincoln, NE: University of Nebraska Press, 2006). 'Keeping Up Appearances' is the title to Owensby's Chapter 5. Of these works, Besse, Putnam, and Francois have the most to say about domestic labor.

${ }^{25}$ Mary Douglas and Baron Isherwood argue that consumption of goods 'has a double role in providing subsistence and in drawing lines of social relationships', conceptualized by Bourdieu as 'cultural capital'. M. Douglas and B. Isherwood, The World of Goods: Towards an Anthropology of Consumption (New York, NY: Basic Books, 1968), 39; Bourdieu, Distinction.

${ }^{26}$ A. Stoler, Carnal Knowledge and Imperial Power: Race and the Intimate in Colonial Rule (Berkeley, CA: University of California Press, 2002); K. T. Hansen, Distant Companions: Servants and Employers in Zambia, 1900-1985 (Ithaca, NY: Cornell University Press, 1989); Influential Western studies include T. M. McBride, The Domestic Revolution: The Modernization of Household Services in England and France, 1820-1920 (New York, NY: Holmes \& Meier, 1976); S. C. Maza, Servants and Masters in Eighteenth-Century France: The Uses of Loyalty (Princeton, NJ: Princeton University Press, 1983); D. M. Katzman, Seven Days a Week: Women and Domestic Service in Industrializing America (Urbana, IL: University of Illinois Press, 1981).

${ }^{27}$ A. Zulawski, 'Social Differentiation, Gender, and Ethnicity: Urban Indian Women in Colonial Bolivia, 1640-1725', Latin American Research Review, 25/2 (1990): 93-113; Gill, Precarious Dependencies.

${ }^{28}$ L. Davidoff and C. Hall, Family Fortunes: Men and Women of the English Middle Class, 1780-1850 (Chicago, IL: University of Chicago Press, 1987), 30; V. M. Macías-González, 'The Largatijo at The High Life: Masculine Consumption, Race, Nation, and Homosexuality in Porfirian Mexico', in R. M. Irwin, E. J. McCaughan, and M. R. Nasser (eds.), The Famous 41: Sexuality and Social Control in Mexico, 1901 (New York, NY: Palgrave Macmillan, 2003), $227-50$.

'Inconspicuous consumption' is from A. Vickery, 'Women and the World of Goods: A Lanchashire Consumer and Her Possessions, 1751-81', in J. Brewer and R. Porter (eds.) Consumption and the World of Goods (London: Routledge, 1993), 279. See also E. Jelin, 'Social Relations of Consumption: The Urban Popular Household', in Jelin (ed.), Family, Household, 165-96; J. Boydston, 'To Earn Her Daily Bread: Housework and Antebellum Working-Class Subsistence', Radical History Review, 35 (1986): 7-25; Francois, Culture of Everyday Credit.

${ }^{29}$ A. J. Bauer, 'Millers and Grinders: Technology and Household Economy in Meso-America', Agricultural History, 64/1 (Winter 1990): 4, 10 
${ }^{30}$ T. Lozano, 'Formas de union y vida familiar', in Vida cotidiana y cultura en el Mexico virreinal (México: Instituto Nacional de Atropologîa y Historia, 2000), 194; P. Gonzalbo Aizpuru, 'Familia y convivencia en la ciudad de México a fines del Siglo XVIII', in P. Gonzalbo Aizpuru (ed.), Familias iberoamericanas. Historia, identidad y conflictos (México: El Colegio de México, 2001), 170; Chambers, From Subjects to Citizens, 95-6.

${ }^{31}$ Socolow, Women, 117; McCreery, Sweat of Their Brow, 102-3.

${ }^{32}$ C. R. Boxer, Women in Iberian Expansion Overseas, 1415-1815: Some Facts, Fancies and Personalities (London: Trinity Press, 1965), 20

${ }^{33}$ E. Kuznesof, 'A History of Domestic Service in Spanish America, 1492-1980', in Chaney and Garcia Castro (eds.), Muchachas No More, 17-35.

${ }^{34}$ Mondragón Barrios, Esclavos, 46. See also R. D. Cope, The Limits of Racial Domination: Plebeian Society in Colonial Mexico City, 1660-1720 (Madison, WI: University of Wisconsin Press, 1994), 13-14, 96. On the reflection of slave attire on the owner's prestige in Brazil, see S. Hunold Lara, 'The Signs of Color: Women's Dress and Racial Relations in Salvador and Rio de Janeiro, ca. 1750-1815', Colonial Latin American Review, 1997 6(2): 205-24.

${ }^{35}$ Mondragón Barrios, Esclavos, 65-6; Cope, Limits of Racial Domination, 95-6; F. T. Proctor, 'Afro-Mexicen Slave Labor in the Obrajes de Paños of New Spain, Seventeenth and Eighteenth Centuries', The Americas, 60/1 (July 2003): 33-58; T. Calvo, 'Círculos de poder en la Guadalajara del siglo xvii', in Vida cotidiana y cultura en el Mexico virreinal (México: Instituto Nacional de Atropologîa y Historia, 2000), 267-80; Romano, Housecraft and Statecraft.

${ }^{36}$ T. Meldrum, Domestic Service and Gender, 1660-1750: Life and Work in the London Household (Harlow/London: Longman, 2000); B. Hill, Servants: English Domestics in the Eighteenth Century (Oxford: Clarendon, 1996); Romano, Housecraft and Statecraft; Stoler, Carnal Knowledge; Hansen, Distant Companions; M. Strobel, 'Gender, Sex and Empire', in M. Adas (ed.), Islamic and European Expansion: The Forging of a Global Empire (Philadelphia, PA: Temple University Press, 1993), 345-75; B. Premo, 'Misunderstood Love: Children and Wetnurses, Creoles and Kings in Lima's Enlightenment', Colonial Latin American Review, 14/2 (December 2005): 231-61.

${ }^{37}$ A. M. Alonso, Thread of Blood: Colonialism, Revolution, and Gender on Mexico's Northern Frontier (Tucson, AZ: University of Arizona Press, 1995), 66-8; Socolow, Women, 117-18; Mangan, Trading Roles, 45.

${ }^{38}$ Vergara Ormeño, 'Artesanos y Sirvientas', 40-2, 50; B. Premo, Children of the Father King: Youth, Authority, and Legal Minority in Colonial Lima (Chapel Hill, NC: University of North Carolina Press, 2005), 14. On the hierarchy of domestic staffs, see Socolow, Women, 117; McCreery, Sweat of Their Brow, 102; Arrom, Women, 187.

${ }^{39}$ G. R. Andrews, Afro-Latin America, 1800-2000 (Oxford: Oxford University Press, 2004), 15.

${ }^{40}$ K. Burns, Colonial Habits: Convents and Spiritual Economy of Cuzco, Peru (Durham, NC: Duke University Press, 1999), 112-14, 119-20.

${ }^{41}$ For discussion of censuses as social constructions and their limitations, see Premo, Children of the Father King; Arrom, Women, 155-8; Porter, Working Women; Hutchison, Labors Appropriate To Their Sex; Putnam, Company They Kept; Farnsworth-Alvear, Dulcinea in the Factory.

${ }^{42}$ Premo, Children, 47; M. Velázquez Castro, 'La mujeres son menos negras: el caso de las mujeres esclavas en la Lima del siglo XIX, in Henriquez (ed.), El hezicho de las imágnes, 57-97. Hunefeldt, Paying the Price, 98 . The 1790 census listed 2,903 'sirvientes de castas libres' (1,284 male, or 44 percent, and 1,619 female, or 56 percent) and 9,229 'esclavos' ( 5,063 male, or 55 percent, and 4,166 female, or 45 percent). 'Plan Demostrativo de la poblacion comprehendida en el vecinto de la ciudad de Lima', in Mercurio Peruano, tomo I, 1791, Edicion Facscimilar (Lima: Biblioteca Nacional del Peru, 1964), 96-7. The total population for Lima in 1790 was 52,627 ( 25,737 male, 26,890 female)

${ }^{43}$ Socolow, Women, 144-5.

${ }^{44}$ Premo, 'Misunderstood Love'; Premo, Children of the Father King, 52-4; Socolow, Women, 118; Andrews, Afro-Latin America, 15; T. Calvo, 'The Warmth of the Hearth: Seventeenth-Century Guadalajaran Families', in A. Lavrin (ed.), Sexuality and Marriage in Colonial Latin America (Lincoln, NE: University of Nebraska Press, 1989), $290-1$.

${ }^{45}$ Francois, Culture of Everyday Credit, 35, 321. The identified 'esclavo' is virtually absent; only color designations can be used to find potentially enslaved persons. Arrom's sample of the same census found 75 percent of the domestic servants to be female. Arrom, Women, 106-9.

${ }^{46}$ Hunefeldt, Paying the Price, 120.

${ }^{47}$ Graham, House and Street, 79; Premo, Children of the Father King, 50, 54; Calvo, 'Warmth of the Hearth', 301-2: Blum, 'Cleaning the Revolutionary Household', 73; Burns, Colonial Habits; Arrom, Women, 188; S. M. Arrom, Containing the 
Poor: The Mexico City Poor House, 1774-1871 (Durham, NC: Duke University Press, 2000); Blum, 'Cleaning the Revolutionary Household'; Premo, Children; Putnam, 'Work, Sex, and Power', 142.

${ }^{48}$ B. Ruiz Gatyán F., 'Un grupo trabajador importante no includio en la historia laboral mexicana (trabajadoras domésticas)', in E. C. Frost (ed.), El trabajo y los trabajadores en la historia de México (México: El Colegio de México, 1979), 435; M. P. Costeloe, The Central Republic in Mexico, 1835-46: Hombres de Bien in the Age of Santa Anna (Cambridge: Cambridge University Press, 1993), 19-20; Parker, Idea of the Middle Class, 27, 61; Gill, Precarious Dependencies, 51-3; B. W. Higman, 'Domestic Service in Jamaica since 1750', in Chaney and Garcia Castro (eds.), Muchachas No More, 44.

49 Hahner, Emancipating the Female Sex, 9.

${ }^{50}$ A. J. Bauer, Goods, Power, History: Latin America's Material Culture (Cambridge: Cambridge University Press, 2001 ); B. Orlove, (ed.), The Allure of the Foreign: Imported Goods in Postcolonial Latin America (Ann Arbor, MI: University of Michigan Press, 1997); S. B. Bunker, '"Consumers of Good Taste": Marketing Modernity in Northern Mexico, 1890-1910', Mexican Studies/Estudios Mexicanos, $12 / 2$ (Summer 1997): 227-69; Besse, Restructuring Patriarchy, 19.

${ }^{51}$ Graham, House and Street, 46. Graham provides detailed descriptions of the different complex tasks done by multiple service categories in the nineteenth century.

52

${ }^{2}$ Hutchison, Labors Appropriate to their Sex, 158-60, 238; Arrom, Containing the Poor, 95-6, 249-50; Blum, 'Cleaning the Revolutionary Household'; B. Weinstein, 'Unskilled Worker, Skilled Housewife: Constructing the Working-Class Woman in Sao Paulo, Brazil', in French and James (eds.), Gendered Worlds, 72-99; Hahner, Emancipating the Female Sex, 48-50; Besse, Restructuring Patriarchy, 98-104.

${ }^{53}$ Hutchison, Labors Appropriate to Their Sex, 12, quote 160-1: Klubock, Contested Communities.

${ }^{54}$ Besse, Restructuring Patriarchy, 78-9.

${ }^{55}$ On the discourse on mothering, C. Ramos-Escandon, 'The Social Construction of Wife and Mother: Women in Porfirian Mexico, 1880-1917', in M. J. Maynes, A. Waltner, B. Soland, and U. Strasser (eds.), Gender, Kinship, Power: A Comparative and Interdisciplinary History (New York, NY: Routledge, 1996), 275-85; Besse, Restructuring Patriarchy, 87109; Arrom, Women of Mexico City, 85-6, 260-8; Hahner, Emancipating the Female Sex, 47-53; Hutchson, Labors Appropriate to Their Sex, 235

${ }^{56}$ Micaela di Leonardo's defines the 'work of kinship' as 'visits, letters, presents, cards, and telephone calls to kin; services, commodities, and money exchanged among kin; and the organization of holiday gatherings'. M. di Leonardo, The Varieties of Ethnic Experience: Kinship, Class, and Gender Among California Italian-Americans (Ithaca, NY: Cornell University Press, 1984), 194; Besse, Restructuring Patriarchy, 13. For the work of mothering in British working and middle classes, see J. Lewis (ed.), Labour and Love: Women's Experience of Home and Family, 1850-1940 (London: Blackwell, 1986). For labor of housewives in the U.S., see Strasser, Never Done; Cowen, More Work for Mother.

${ }^{57}$ D. J. Guy, 'Emilio and Gabriela Coni: Reformers, Public Health, and Working Women', in W. H. Beezley and J. Ewell (eds.), The Human Tradition in Modern Latin America (Wilmington, Scholarly Resources, 1997), 88

58 J. McC. Heyman, Life and Labor on the Border: Working People of Northeastern Sonora, Mexico, 1886-1986 (Tucson AZ: University of Arizona Press, 1991), 17.

${ }^{59}$ Putnam, Company They Kept, 7.

${ }^{60}$ Putnam, 'Work, Sex, and Power', 142.

${ }^{61}$ Hutchison, Labors Appropriate to Their Sex, 33.

62 Hahner, Emancipating the Female Sex, 93, 98; Hutchison, Labors Appropriate To Their Sex, 33; Putnam, Company They Kept, 149.

${ }^{63}$ In Mexico City, a third of households were headed by women in the first half of the century, and over 40 percent of the female population widowed throughout the century. Other Latin American cities such as Guadalajara, Caracas, Santiago, São Paulo, Belo Horizonte, and Iguape also had levels of female headship from 24 to 45 percent. These numbers are higher than eighteenth-century England's 16 percent. Calvo, 'Warmth of the Hearth'; E. Kuznesof, 'Gender Ideology, Race, and Female-Headed Households in Urban Mexico, 1750-1850', in Uribe-Uran (ed.), State and Society, 161-5; Arrom, Women, 120,132, 166, 186, 197; Socolow, Women, 75-6;

L. Weatherill, 'The Meaning of Consumer Behavior in Late Seventeenth- and Early Eighteenth- Century England', in Brewer and Porter (eds.), Consumption, 211.

64 J. de Alencar, Senhora: Profile of a Woman (1875), trans. C. Feldmann Edinger (Austin, TX: University of Texas Press, 1994), 69, 27. The work of the mother and sister are highlighted on 26-30. 
${ }^{65}$ Francois, Culture of Everyday Credit, 162, 180-1. Literature is a promising source to get at representations of housework in Latin America, one used a great deal in the comparative historiography on servants. A. Scott-Prelorentzos, The Servant in German Enlightenment Comedy (Edmonton: University of Alberta Press, 1982); S. Yates, Maid and Mistress: Feminine Solidarity and Class Difference in Five Nineteenth-Century French Texts (New York, NY: Peter Lang, 1991); B. Robbins, The Servant's Hand: English Fiction from Below (New York, NY: Columbia University Press, 1986).

66

Hutchison, Labors Appropriate to Their Sex, 161; Besse, Restructuring Patriarchy

${ }^{67}$ Censo General de la Republica del Peru formado en 1876. Tomo VI. Departamentos de Lima, Loreto y Moquegua (Lima: Imp. Del Teatro, 1878), 810; Censo de la República de Cuba bajo la Administración Provisional de Los Estados Unidos 1907 (Washington: Oficino [sic] del Censo de los Estados de Unidos, 1908).

${ }^{68}$ On Europe, see Romano, Housecraft and Statecraft, xx-xxi; R. Sarti, Europe at Home: Family and Material Culture, 1500-1800 (New Haven, CT: Yale University Press, 2002). For Africa, Hansen, Distant Companions; 59-61; K. T. Hansen (ed.), African Encounters with Domesticity (New Brunswick, NJ: Rutgers University Press, 1992); G. Mianda, 'Colonialism, Education, and Gender Relations in the Belgian Congo: The Évolué Case', in J. Allman, S. Geiger and N. Musisi, (eds.), Women in African Colonial Histories (Bloomington, IN: Indiana University Press, 2002), 144-63.

${ }^{69}$ B. S. Cohn, Colonialism and Its Forms of Knowledge: The British in India (Princeton, NJ: Princeton University Press, 1996), 100; M. A. Procida, Married to the Empire: Gender, Politics and Imperialism in India, 1883-1947 (Manchester: Manchester University Press, 2002). It was very different for high caste Hindu households: cooks had to be Brahmin, as did men and women serving the table. Ayahs had to be at least middle caste. No Muslim, Anglo-Indian or untouchable could be allowed inside the home. They could be employed outside as butlers, drivers, in stables and gardens, etc., but could have nothing to do with kitchens or food or handling children. Washermen and barbers were of specific untouchable castes or could be Muslims. S. Channa, personal communication, April, 2003. Females were as prevalent as males as servants in middle class Indian household service in colonial Bengal. S. M. Banerjee, 'Down Memory Lane: Representations of Domestic Workers in Middle Class Personal Narratives of Colonial Bengal', Journal of Social History, (Spring 2004): 681-706.

${ }^{70}$ P. Gonzalbo Aizpuru, Introducción a la historia de la vida cotidiana (México: El Colegio de México, 2006 ), 231.

71 D. J. Guy, 'Women, Peonage, and Industrialization: Argentina, 1810-1914', Latin American Research Review, 16/3 (1981): 65-89; Hutchison, Labors Appropriate to Their Sex; Besse, Restructuring Patriarchy, Porter, Working Women.

72 Hansen, Distant Companions, 151-3.

${ }^{73}$ Hahner, Emancipating the Female Sex, 12, 91-2, 97; Lauderdale Graham, House and Street, 20-2; Besse, Restructuring Patriarchy, 144-5.

${ }^{74}$ Higman, 'Domestic Service in Jamaica', 48.

${ }^{75}$ D. Ladd, The Mexican Nobility at Independence, 1780-1826 (Austin, TX: University of Texas Press, 1976), 67; Francois, Culture of Everyday Credit, 82-3.

${ }^{76}$ Mrs A. Tweedie, Mexico As / Saw It (London: Horst and Blacket Limited, 1901), 220.

${ }^{77}$ Francois, Culture of Everyday Credit, 163-9.

${ }^{78}$ Hutchison, Labors Appropriate to Their Sex, 25-6, 43-5.

${ }^{79}$ A. E. Talles and R. Poczter, Muestra del censo de poblacion de la ciudad de Buenos Aires de 1855 (Buenos Aires: Instituto Torduato di Tella, Centro de Investigaciones Sociales, 1968), 68; G. R. Andrews, 'Race versus Class Association: The Afro-Argentines of Buenos Aires, 1850-1900', Journal of Latin American Studies, 11/1 (1979): 22.

${ }^{80}$ Talles and Poczter, Muestra del censo de poblacion, 70; Cárdenas, Ramona y el robot, 24-5, 37; Andrews, 'Race Versus Class Association', 25-6.

${ }^{81}$ Gill, Precarious Dependencies, 20, 51 .

${ }^{82}$ See D. E. Hojman, 'Land Reform, Female Migration and the Market for Domestic Service in Chile', Journal of Latin American Studies, 21 (1989): 105-32.

${ }^{83}$ M. Goldsmith Connelly, 'Uniformes, escobas, y lavaderos: el proceso productivo del servicio domestico', in Oliveira (ed.), Trabajo, Poder, y Sexualidad, 103-32.

${ }^{84}$ D. Levenson-Estrada, 'The Loneliness of Working-Class Feminism: Women in the "Male World" of Labor Unions, Guatemala City, 1970s', in French and James (eds.), Gendered Worlds, 209.

${ }^{85}$ T. R. Veccia, "My Duty as a Woman": Gender Ideology, Work, and Working-Class Women's Lives in São Paulo, Brazil, 1900-1950', in French and James (eds.), Gendered Worlds, 118-19, 129-30, 132-3. 
${ }^{86}$ Olcott, Revolutionary Women, 104.

${ }^{87}$ Weinstein, 'Unskilled Worker, Skilled Housewife', 86, 92.

${ }^{88}$ Farnsworth-Alvear, Dulcinea in the Factory, 225.

${ }^{89}$ Gill, Precarious Dependencies, 52.

90 Hojman, 'Domestic Service in Chile', 111; Goldsmith, 'Uniformes, escobas, y lavaderos', 115-17.

${ }^{91}$ F. G. Chambers, Face to Face With the Mexicans (Carbondale, IL: Southern Illinois University, 1966), 50, 54; Higman, 'Domestic Service in Jamaica', 47.

92 Gill, Precarious Dependencies, 53. For debate about the degree to which appliances lessened or increased the work in households in the U.S., see Cowen, More Work for Mother.

${ }^{93}$ Bauer, 'Millers and Grinders'; J. M. Pilcher, Que Vivan Los Tamales! Food and the Making of Mexican Identity (Albuquerque, NM: University of New Mexico Press, 1998), 100-3: Porter, Working Women, 43, 47; Olcott, Revolutionary Women, 148.

${ }^{94}$ Besse, Restructuring Patriarchy, 147, 182; I. Duarte, 'Household Workers in the Dominican Republic: A Question for the Feminist Movement', in Chaney and Garcia Castro (eds.), Muchachas No More, 198-9.

${ }^{95}$ Besse, Restructuring Patriarchy, 162.

${ }^{96}$ On 'raced gender', see Farnsworth-Alvear, Dulcinea in the Factory, 29. For reputations of servants, see McCreery, Sweat of Their Brow, 102; Besse, Restructuring Patriarchy, 45, 104; Farnsworth-Alvear, Dulcinea in the Factory, 80-1. For modern representations of servants, see C. B. Flora, 'Domestic Service in the Latin American Fotonovela', in Chaney and Garcia Castro (eds.), Muchachas No More, 143-59.

${ }^{97}$ Premo, 'Misunderstood Love'; McCreery, Sweat of Their Brow, 102-3; Farnsworth-Alvear, Dulcinea in the Factory, 81; Francois, Culture of Everyday Credit, 184-5.

${ }^{98}$ Andrews, 'Race Versus Class Association', 25

${ }^{99}$ M. A. Johnson, '“Decent and Fair": Aspects of Domestic Service in Jamaica, 1920-1970', Journal of Caribbean History, 30/1-2 (1996): 83-106; Farnsworth-Alvear, Dulcinea in the Factory, 67, 204.

${ }^{100}$ Veccia, "'My Duty as a Woman"', 129; J. D. French and D. James, 'Oral History, Identity Formation, and Working-Class Mobilization', in French and James (eds.), Gendered Worlds, 301; Besse, Restructuring Patriarchy, 74-7.

${ }^{101}$ Gonzalbo, Introduccion a la historia de la vida cotidinia, 169; Hutchison, Labors Appropriate to Their Sex, 5-6, 54.

${ }^{102}$ Porter, Working Women, 4, 8.

${ }^{103}$ Olcott, Revolutionary Women, 149.

104 Olcott, Revolutionary Women, 120, 141-9, 220, 225-7.

$105 \mathrm{~J}$. Fisher, 'Gender and the State in Argentina: The Case of the Sindicato de Amas de Casa', in E. Dore and M. Molyneaux (eds.), Hidden Histories of Gender and the State in Latin America (Durham, NC: Duke University Press, 2000), 322-45; D. Barrios de Chungarra with M. Viezzer, Let Me Speak! Testimony of Domitila, a Woman of the Bolivian Tin Mines, trans. V. Ortiz (New York, NY: Monthly Review Press, 1978); H. Tinsman, Partners in Conflict: The Politics of Gender, Sexuality, and Labor in the Chilean Agrarian Reform, 1950-1973 (Durham, , NC: Duke University Press, 2002); M. Molyneaux, 'State, Gender, and Institutional Change: The Federación de Mujeres Cubanas', in Dore and Molyneaux (eds.), Hidden Histories of Gender, 291-321; Chaney and Garcia Castro, Muchachas No More.

${ }^{106}$ D. Wall, 'Family Meals and Evening Parties: Constructing Domesticity in Nineteenth-Century Middle-Class New York', in J. A. Delle, S. A. Mrozowski, and R. Paynter (eds.), Lines That Divide: Historical Archaeologies of Race, Class, and Gender (Knoxville, TN: University of Tennessee Press, 2000), 111-32.

${ }^{107}$ In 1980, 96 percent of Chilean domestic servants were female, 98 percent in Argentina, and 96 percent in Brazil. For Peru, the 1972 census reports 90 percent of the domestic service force in Lima as female. T. Gálvez and R. Rodaro, 'Housework for Pay in Chile: Not Just Another Job', in Chaney and Garcia Castro (eds.), Muchachas No More, 307; M Gogna, 'Domestic Workers in Buenos Aires', in op. cit., 84; H. Pereira de Melo, 'Feminists and Domestic Workers in Rio de Janiero', in op. cit., 246; M. Smith, 'Where is María Now? Former Domestic Workers in Peru', in op. cit., 130. 
${ }^{108}$ T. Schellekens and A. van der Schoot, 'Household Workers in Peru: The Difficult Road to Organization', in op. cit., 291.

\section{Bibliography}

de Alencar, J., Senhora: Profile of a Woman, trans. C. Feldmann Edinger (Austin, TX: University of Texas Press, 1994).

Alonso, A. M., Thread of Blood: Colonialism, Revolution, and Gender on Mexico's Northem Frontier (Tucson, AZ: University of Arizona Press, 1995).

Andrews, G. R., 'Race versus Class Association: The Afro-Argentines of Buenos Aires, 18501900', Journal of Latin American Studies, 11/1 (1979): 19-39.

Andrews, G. R., Afro-Latin America, 1800-2000 (Oxford: Oxford University Press, 2004).

Arizpe, L., 'Women in the Informal Labor Sector: The Case of Mexico City', Signs, 3 (Fall 1977): 25-37.

Arrom, S. M., The Women of Mexico City, 1790-1857 (Stanford, CA: Stanford University Press, 1985).

Arrom, S. M., Containing the Poor: The Mexico City Poor House, 1774-1871 (Durham, NC: Duke University Press, 2000).

Balbo, L., 'The Servicing Work of Women and the Capitalist State', Political Power and Social Theory, 3 (1982): 251-70.

Banerjee, S. M., 'Down Memory Lane: Representations of Domestic Workers in Middle Class Personal Narratives of Colonial Bengal', Journal of Social History, (Spring 2004): 681-706.

Barrios de Chungarra, D., with Viezzer, M., Let Me Speak! Testimony of Domitila, a Woman of the Bolivian Tin Mines, trans. V. Ortiz (New York, NY: Monthly Review Press, 1978).

Bauer, A. J., 'Millers and Grinders: Technology and Household Economy in Meso-America', Agricultural History, 64/1 (Winter 1990): 1-17.

Bauer, A. J., Goods, Power, History: Latin America's Material Culture (Cambridge: Cambridge University Press, 2001).

Besse, S. K., Restructuring Patriarchy: The Modemization of Gender Inequality in Brazil, 19141940 (Chapel Hill, NC: University of North Carolina Press, 1996).

Blum, A. S., 'Cleaning the Revolutionary Household: Domestic Servants and Public Welfare in Mexico City, 1900-1935', Journal of Women's History, 15/4 (2004): 67-90.

Blum, A., Domestic Economies: Families, Work, and Welfare in Mexico City, 1884-1943 (Lincoln, NE: University of Nebraska Press, forthcoming).

Boris, E., 'The Home as Workplace: Deconstructing Dichotomies', International Review of Social History, 39 (1994): 415-28.

Boserup, E., Women's Role in Economic Development (New York, NY: St Martin's Press, 1970).

Bourdieu, P., Distinction: A Social Critique of the Judgment of Taste, trans. R. Nice (Cambridge, MA: Harvard University Press, 1984).

Bourdieu, P., Language and Symbolic Power (Cambridge: Cambridge University Press, 1991).

Boxer, C. R., Women in Iberian Expansion Overseas, 1415-1815: Some Facts, Fancies and Personalities (London: Trinity Press, 1965)

Boydston, J., 'To Earn Her Daily Bread: Housework and Antebellum Working-Class Subsistence', Radical History Review, 35 (1986): 7-25. 
Boydston, J., Home and Work: Housework, Wages, and the Ideology of Labor in the Early Republic (Oxford: Oxford University Press, 1993).

Bunker, S. B., "Consumers of Good Taste": Marketing Modernity in Northern Mexico, 1890 1910', Mexican Studies/Estudios Mexicanos, $12 / 2$ (Summer 1997): 227-69.

Bunster, X., and Chaney, E. M., Sellers and Servants: Working Women in Lima Peru (New York, NY: Praeger Publishers, 1985).

Burns, K., Colonial Habits: Convents and Spiritual Economy of Cuzco, Peru (Durham, NC: Duke University Press, 1999).

Calvo, T., 'The Warmth of the Hearth: Seventeenth-Century Guadalajaran Families', in A Lavrin (ed.), Sexuality and Marriage in Colonial Latin America (Lincoln, NE: University of Nebraska Press, 1989), 287-312.

Calvo, T., 'Círculos de poder en la Guadalajara del siglo xvii', Vida cotidiana y cultura en el Mexico virreinal (México: Instituto Nacional de Atropologîa y Historia, 2000), 267-80.

Cárdenas, I. L., Ramona y el robot: el servicio domestico en barrios prestigios de Buenos Aires (1895-1985) (Buenos Aires: Ediciones Busqueda, 1986).

de Certeau, M., The Practice of Everyday Life, trans. S. F. Rendall (Berkeley, CA: University of California Press, 1984), 39-40.

Chambers, F. G., Face to Face With The Mexicans (Carbondale, IL: Southern Illinois University, 1966).

Chambers, S. C., From Subjects to Citizens: Honor, Gender, and Politics in Arequipa, Peru, 1780-1854 (University Park, PA: Pennsylvania State Press, 1999).

Chaney, E. M., and Garcia Castro, M. (eds.), Muchachas No More: Household Workers in Latin America and the Caribbean (Philadelphia, PA: Temple University Press, 1989).

Cohn, B. S., Colonialism and Its Forms of Knowledge: The British in India (Princeton, NJ: Princeton University Press, 1996).

Cope, R. D., The Limits of Racial Domination: Plebeian Society in Colonial Mexico City, 1660 1720 (Madison, WI: University of Wisconsin Press, 1994).

Costeloe, M. P., The Central Republic in Mexico, 1835-46: Hombres de Bien in the Age of Santa Anna (Cambridge: Cambridge University Press, 1993).

Cowan, R. S., More Work for Mother (New York, NY: Basic Books, 1983).

Davidoff, L., and Hall, C., Family Fortunes: Men and Women of the English Middle Class, 1780-1850 (Chicago, IL: University of Chicago Press, 1987).

Deere, C. D., and Leon, M., 'Liberalism and Married Women's Property Rights in Nineteenthcentury Latin America', Hispanic American Historical Review, 85/4 (2005) $627-78$.

Douglas, M., and Isherwood, B., The World of Goods: Towards an Anthropology of Consumption (New York, NY: Basic Books, 1968).

Duarte, I., 'Household Workers in the Dominican Republic: A Question for the Feminist Movement', in E. Chaney and M. Garcia Castro (eds.), Muchachas No More: Household Workers in Latin America and the Caribbean (Philadelphia, PA: Temple University Press, 1989), 197-220.

Farnsworth-Alvear, A., Dulcinea in the Factory: Myths, Morals, Men, and Women in Colombia's Industrial Experiment, 1905-1960 (Durham, NC: Duke University Press, 2000). 
Fisher, J., 'Gender and the State in Argentina: The Case of the Sindicato de Amas de Casa', in E. Dore and M. Molyneaux (eds.), Hidden Histories of Gender and the State in Latin America (Durham, NC: Duke University, 2000), 322-45.

Flora, C. B., 'Domestic Service in the Latin American Fotonovela', in E. Chaney and M. Garcia Castro (eds.), Muchachas No More: Household Workers in Latin America and the Caribbean (Philadelphia, PA: Temple University Press, 1989), 143-159.

Fortunati, L., The Arcane of Reproduction; Housework, Prostitution, Labor and Capital, trans. $\mathrm{H}$. Creek (New York, NY: Autonomedia, 1995).

Francois, M. E., A Culture of Everyday Credit: Housekeeping, Pawnbroking, and Governance in Mexico City, 1750-1920 (Lincoln, NE: University of Nebraska Press, 2006).

French, J. D., and James, D., 'Oral History, Identity Formation, and Working-Class Mobilization', in J. French and D. James (eds.), The Gendered Worlds of Latin American Women Workers (Durham, NC: Duke University Press, 1997), 297-313.

Gálvez, T., and Rodaro, R., 'Housework for Pay in Chile: Not Just Another Job', in E. Chaney and M. Garcia Castro (eds.), Muchachas No More: Household Workers in Latin America and the Caribbean (Philadelphia, PA: Temple University Press, 1989), 30722.

Gamber, W., The Female Economy: The Millinery and Dressmaking Trades, $1860-1930$ (Urbana, IL: University of Illinois Press, 1997).

Gill, L., Precarious Dependencies: Gender, Class, and Domestic Service in Bolivia (New York, NY: Columbia University Press, 1994).

Gogna, M., 'Domestic Workers in Buenos Aires', in E. Chaney and M. Garcia Castro (eds.), Muchachas No More: Household Workers in Latin America and the Caribbean (Philadelphia, PA: Temple University Press, 1989), 83-104.

Goldsmith Connelly, M., 'Uniformes, escobas, y lavaderos: el proceso productivo del servicio domestico', in O. de Oliveira (ed.), Trabajo, poder, y sexualidad (México: El Colegio de México, 1989), 103-32.

Gonzalbo Aizpuru, P., 'Familia y convivencia en la ciudad de México a fines del Siglo XVIII', in P. Gonzalbo Aizpuru (ed.), Familias iberoamericanas. Historia, identidad y conflictos (México: El Colegio de México, 2001), 163-80.

Gonzalbo Aizpuru, P., Introducción a la historia de la vida cotidiana (México: El Colegio de México, 2006).

Graham, S. L., House and Street: The Domestic World of Servants and Masters in NineteenthCentury Rio de Janeiro (Austin: University of Texas, 1988).

Gramsci, A., Selections from the Prison Notebooks (New York, NY: International Publishers, 1971).

Gregson, N., and Lowe, M., Servicing the Middle Classes: Class, Gender and Waged Domestic Labor in Contemporary Britain (London: Routledge, 1994).

Guy, D. J., 'Women, Peonage, and Industrialization: Argentina, 1810-1914', Latin American Research Review, 16/3 (1981): 65-89.

Guy, D. J., 'Emilio and Gabriela Coni: Reformers, Public Health, and Working Women', in W. H. Beezley and J. Ewell (eds.), The Human Tradition in Modem Latin America (Wilmington: Scholarly Resources, 1997), 77-92.

Hahner, J., Emancipating the Female Sex: The Struggle for Women's Rights in Brazil, 18501940 (Durham, NC: Duke University Press, 1990).

Hansen, K. T., Distant Companions: Servants and Employers in Zambia, 1900-1985 (Ithaca, NY: Cornell University Press, 1989). 
Hansen, K. T. (ed.), African Encounters with Domesticity (New Brunswick, NJ: Rutgers University Press, 1992).

Hartmann, H., 'Capitalism, Patriarchy and job segregation by sex', Signs, 1/3 (1976): 17-69.

Heyman, J. McC., Life and Labor on the Border: Working People of Northeastern Sonora, Mexico, 1886-1986 (Tucson, AZ: University of Arizona Press, 1991).

Higman, B. W. 'Domestic Service in Jamaica since 1750', in E. Chaney and M. Garcia Castro (eds.), Muchachas No More: Household Workers in Latin America and the Caribbean (Philadelphia, PA: Temple University Press, 1989), 37-66.

Hill, B., Servants: English Domestics in the Eighteenth Century (Oxford: Clarendon, 1996).

Hojman, D. E., 'Land Reform, Female Migration and the Market for Domestic Service in Chile', Journal of Latin American Studies, 21 (1989): 105-32.

Hondagneu-Sotelo, P., Domestica: Immigrant Workers Cleaning and Caring in the Shadows of Affluence (Berkeley, CA: University of California Press, 2001).

Hunefeldt, C., Paying the Price of Freedom: Family and Labor among Lima's Slaves, 18001854 (Berkeley, CA: University of California Press, 1994).

Hunefeldt, C., Liberalism in the Bedroom: Quarrelling Spouses in Nineteenth-Century Lima (University Park, PA: Pennsylvania State University Press, 2000).

Hunold Lara, S., 'The Signs of Color: Women's Dress and Racial Relations in Salvador and Rio de Janeiro, ca. 1750-1815', Colonial Latin American Review, 6/2 (1997): 205-24

Hutchison, E. Q., Labors Appropriate to Their Sex: Gender, Labor, and Politics in Urban Chile, 1900-1930 (Durham, NC: Duke University Press, 2001).

Jelin, E. (ed.), Family, Household and Gender Relations in Latin America (London: Kegan Paul International, UNESCO, 1991).

Jelin, E., 'Social Relations of Consumption: The Urban Popular Household', in E. Jelin (ed.), Family, Household, and Gender Relations in Latin America (London: Kegan Paul International, UNESCO, 1991), 165-96.

Johnson, M. A. "'Decent and Fair”: Aspects of Domestic Service in Jamaica, 1920-1970', Journal of Caribbean History, 30/1-2 (1996): 83-106.

Karasch, M. C., Slave Life in Rio de Janeiro: 1808-1850 (Princeton, NJ: Princeton University Press, 1987).

Katzman, D. M., Seven Days a Week: Women and Domestic Service in Industrializing America (Urbana, IL: University of Illinois Press, 1981).

Klubock, T. M., Contested Communities: Class, Gender, and Politics in Chile's El Tentiente Copper Mine, 1904-1951 (Durham, NC: Duke University Press, 1996).

Kuznesof, E., 'A History of Domestic Service in Spanish America, 1492-1980', in E. Chaney and M. Garcia Castro (eds.), Muchachas No More: Household Workers in Latin America and the Caribbean (Philadelphia, PA: Temple University Press, 1989), 1735.

Kuznesof, E., 'Gender Ideology, Race, and Female-Headed Households in Urban Mexico, 1750-1850', in V. M. Uribe-Uran (ed.), State and Society in Spanish America during the Age of Revolution (Wilmington: Scholarly Resources, 2001), 149-70.

Ladd, D., The Mexican Nobility at Independence, 1780-1826 (Austin, TX: University of Texas Press, 1976).

di Leonardo, M., The Varieties of Ethnic Experience: Kinship, Class, and Gender Among California Italian-Americans (Ithaca, NY: Cornell University Press, 1984). 
di Leonardo, M., 'Introduction: Gender, Culture, and Political Economy: Feminist Anthropology in the Postmodern Era', in M. di Leonardo (ed.), Gender at the Crossroads of Knowledge: Feminist Anthropology in the Postmodern Era (Berkeley, CA: University of California Press, 1991), 1-48.

Levenson-Estrada, D., 'The Loneliness of Working-Class Feminism: Women in the "Male World" of Labor Unions, Guatemala City, 1970s', in J. French and D. James (eds.), The Gendered Worlds of Latin American Women Workers (Durham, NC: Duke University Press, 1997), 208-31.

Lewis, J. (ed.), Labour and Love: Women's Experience of Home and Family, 1850-1940 (London: Blackwell, 1986).

Lipsett-Rivera, S., 'Marriage and Family Relations in Mexico during the Transition from Colony to Nation', in V. M. Uribe-Uran (ed.), State and Society in Spanish America during the Age of Revolution (Wilmington: Scholarly Resources, 2001), 126-7.

Lozano, T., 'Formas de union y vida familiar', Vida cotidiana y cultura en el Mexico virreinal (México: Instituto Nacional de Atropología y Historia, 2000), 189-202.

McBride, T. M., The Domestic Revolution: The Modernization of Household Services in England and France, 1820-1920 (New York, NY: Holmes \& Meier, 1976).

McCreery, D. J., The Sweat of Their Brow: A History of Work in Latin America (Armonk, NY: M. E. Sharpe, 2000).

Macías-González, V. M., 'The Largatijo at The High Life: Masculine Consumption, Race, Nation, and Homosexuality in Porfirian Mexico', in R. M. Irwin, E. J. McCaughan, and M. R. Nasser (eds.), The Famous 41: Sexuality and Social Control in Mexico, 1901 (New York, NY: Palgrave Macmillan, 2003), 227-50.

Mangan, J., Trading Roles: Gender, Ethnicity, and the Urban Economy in Colonial Potosi (Durham, NC: Duke University Press, 2005).

Matos Rodriguez, F. V., 'Quien Trabajara? Trabajo domestico, esclavitud urbana, y abolición en San Juan en el siglo xix', Revista de Ciencias Sociales, 4 (1998): 219-45.

Maza, S. C., Servants and Masters in Eighteenth-Century France: The Uses of Loyalty (Princeton, NJ: Princeton University Press, 1983).

Meldrum, T., Domestic Service and Gender, 1660-1750: Life and Work in the London Household (Harlow/London: Longman, 2000).

Mianda, G., 'Colonialism, Education, and Gender Relations in the Belgian Congo: The Évolué Case', in J. Allman, S. Geiger, and N. Musisi (eds.), Women in African Colonial Histories (Bloomington, IN: Indiana University Press, 2002), 144-63.

Molyneaux, M., 'State, Gender, and Institutional Change: The Federación de Mujeres Cubanas', in E. Dore and M. Molyneaux (eds.), Hidden Histories of Gender and the State in Latin America (Durham, NC: Duke University, 2000), 291-321.

Mondragón Barrios, L., Esclavos africanos en la Ciudad de México: El sevicio doméstico durante el siglo XVI (México: CONACULTAINAH, 1999).

Olcott, J., Revolutionary Women in Postrevolutionary Mexico (Durham, NC: Duke University Press, 2005)

de Oliveira, O. (ed.), Trabajo, poder, y sexualidad (México: El Colegio de México, 1989).

Orlove, B. (ed.), The Allure of the Foreign: Imported Goods in Postcolonial Latin America (Ann Arbor, MI: University of Michigan Press, 1997).

Owensby, B., Intimate Ironies: Modernity and the Making of Middle-Class Lives in Brazil (Stanford, CA: Stanford University Press, 1999). 
Parker, D. S., The Idea of the Middle Class: White Collar Workers and Peruvian Society, 19001950 (University Park, PA: Pennsylvania State University Press, 1998).

Pateman, C., The Sexual Contract (Stanford, CA: Stanford University Press, 1988).

Pereira de Melo, H., 'Feminists and Domestic Workers in Rio de Janiero', in E. Chaney and M. Garcia Castro (eds.), Muchachas No More: Household Workers in Latin America and the Caribbean (Philadelphia, PA: Temple University Press, 1989), 363-72.

Pilcher, J. M., Que Vivan Los Tamales! Food and the Making of Mexican Identity (Albuquerque, NM: University of New Mexico Press, 1998).

Porter, S., Working Women in Mexico City: Public Discourses and Material Conditions, 18791930 (Tucson, AZ: University of Arizona Press, 2003).

Premo, B., Children of the Father King: Youth, Authority, and Legal Minority in Colonial Lima (Chapel Hill, NC: University of North Carolina Press, 2005).

Premo, B., 'Misunderstood Love: Children and Wetnurses, Creoles and Kings in Lima's Enlightenment', Colonial Latin American Review, 14/2 (2005): 231-61.

Procida, M. A., Married to the Empire: Gender, Politics and Imperialism in India, 1883-1947 (Manchester: Manchester University Press, 2002).

Proctor, F. T., 'Afro-Mexican Slave Labor in the Obrajes de Paños of New Spain, Seventeenth and Eighteenth Centuries', The Americas, 60/1 (2003): 33-58.

Putnam, L., The Company They Kept: Migrants and the Politics of Gender in Caribbean Costa Rica, 1870-1960 (Chapel Hill, NC: University of North Carolina, 2002).

Putnam, L., 'Work, Sex, and Power in a Central American Export Economy at the Turn of the Twentieth Century', in W. E. French and K. E. Bliss (eds.), Gender, Sexuality, and Power in Latin America Since Independence (Lanham, MD: Rowan and Littlefield, 2007), 133-62.

Radcliffe, S., 'Race and Domestic Service: Migration and Identity in Ecuador', in J. H. Momsen (ed.), Gender, Migration, and Domestic Service (London: Routledge, 1999), 83-97.

Ramos-Escandon, C., 'The Social Construction of Wife and Mother: Women in Porfirian Mexico, 1880-1917', in M. J. Maynes, A. Waltner, B. Soland, and U. Strasser (eds.), Gender, Kinship, Power: A Comparative and Interdisciplinary History (New York, NY: Routledge, 1996), 275-85

Rapp, R., 'Family and Class in Contemporary America', in B. Thorne and M. Yalom (eds.), Rethinking the Family: Some Feminist Questions (New York, NY: Longman, 1982).

Rivas, L. M., 'Invisible Labors: Caring for the Independent Person', in B. Ehrenreich and A. R. Hochschild (eds.), Global Woman: Nannies, Maids, and Sex Workers in the New Economy (New York, NY: Metropolitan Books, 2003), 70-84.

Robbins, B., The Servant's Hand: English Fiction from Below (New York, NY: Columbia University Press, 1986).

Romano, D., Housecraft and Statecraft: Domestic Service in Renaissance Venice, 1400-1600 (Baltimore, MD: Johns Hopkins University Press, 1996).

Rubio, A., and Taussig, M., 'Up off Their Knees: Servanthood in Southwest Colombia', in Female Servants and Economic Development, Michigan Occasional Paper No. 1 (Fall 1978): 5-29.

Ruiz Gatyán, F. B., 'Un grupo trabajador importante no includio en la historia laboral mexicana (trabajadoras domésticas)', in E. C. Frost (ed.), El trabajo y los trabajadores en la historia de México (México: El Colegio de México, 1979).

Salazar Parre-as, R., Servants of Globalization: Women, Migration, and Domestic Work (Stanford, CA: Stanford University Press, 2001). 
Sarti, R., Europe at Home: Family and Material Culture, 1500-1800 (New Haven, CT: Yale University Press, 2002).

Schellekens, T., and van der Schoot, A., 'Household Workers in Peru: The Difficult Road to Organization', E. Chaney and M. Garcia Castro (eds.), Muchachas No More: Household Workers in Latin America and the Caribbean (Philadelphia, PA: Temple University Press, 1989), 291-306.

Scott, J., 'Gender: A Useful Category of Analysis', American Historical Review, 91/5 (1986): 1053-75.

Scott, J. W., The Politics of Gender in History (New York, NY: Columbia University Press, 1988).

Scott-Prelorentzos, A., The Servant in German Enlightenment Comedy (Edmonton: University of Alberta Press, 1982).

Silva Dias, M. O., Power and Everyday Life: The Lives of Working Women in NineteenthCentury Brazil (New Brunswick, NJ: Rutgers University Press, 1995).

Smith, M., 'Where is María Now? Former Domestic Workers in Peru', in E. Chaney and M. Garcia Castro (eds.), Muchachas No More: Household Workers in Latin America and the Caribbean (Philadelphia, PA: Temple University Press, 1989), 127-42.

Socolow, S. M., The Women of Colonial Latin America (Cambridge: Cambridge University Press, 2000)

Sparks, E., Capital Intentions: Female Proprietors in San Francisco, 1850-1920 (Chapel Hill, NC: University of North Carolina Press, 2006).

Steedman, C., 'The Servant's Labour: The Business of Life, England, 1760-1820', Social History, 29/1 (February 2004): 1-29.

Stoler, A., Carnal Knowledge and Imperial Power: Race and the Intimate in Colonial Rule (Berkeley, CA: University of California Press, 2002).

Strasser, S. Never Done: A History of American Housework (New York, NY: Pantheon Press, 1982).

Strobel, M., 'Gender, Sex and Empire', in M. Adas (ed.), Islamic and European Expansion: The Forging of a Global Empire (Philadelphia, PA: Temple University Press, 1993), 34575.

Talles, A. E., and Poczter, R., Muestra del censo de poblacion de la ciudad de Buenos Aires de 1855 (Buenos Aires: Instituto Torduato di Tella, Centro de Investigaciones Sociales, 1968).

Tinsman, H., 'The Indispensable Services of Sisters: Considering Domestic Service in the United States and Latin American Studies', Journal of Women's History, 4/1 (Spring 1992): 37-59.

Tinsman, H., 'Household Patrones: Wife-Beating and Sexual Control in Rural Chile, 19641988', in J. French and D. James (eds.), The Gendered Worlds of Latin American Women Workers (Durham, NC: Duke University Press, 1997), 264-96.

Tinsman, H., Partners in Conflict: The Politics of Gender, Sexuality, and Labor in the Chilean Agrarian Reform, 1950-1973 (Durham, NC: Duke University Press, 2002).

Tweedie, Mrs A., Mexico As I Saw It (London: Horst and Blacket Limited, 1901). Varley, A., 'Women and the Home in Mexican Family Law', in E. Dore and M. Molyneaux (eds.), Hidden Histories of Gender and the State in Latin America (Durham, NC: Duke University, 2000), 238-61.

Veccia, T. R. ' "My Duty as a Woman": Gender Ideology, Work, and Working-Class Women's Lives in São Paulo, Brazil, 1900-1950', in J. French and D. James (eds.), The 
Gendered Worlds of Latin American Women Workers (Durham, NC: Duke University Press, 1997), 100-46.

Velázquez Castro, M., 'La mujeres son menos negras: el caso de las mujeres esclavas en la Lima del siglo XIX', in N. Henríquez (ed.), El hechizo de las imágenes: estatus social, género y etnicidad en la historia peruana (Lima: Fondo Editorial de la Póntificia Universidad Católica del Perú, 2000), 57-97.

Vergara Ormeño, T., 'Artesanos y Sirvientas: El papel de los hombres y las mujeres indigenas en la economía limeña (siglo XVII)', N. Henríquez (ed.), El hechizo de las imágenes: estatus social, género y etnicidad en la historia peruana (Lima: Fondo Editorial de la Póntificia Universidad Católica del Perú, 2000), 33-54.

Vickery, A., 'Women and the World of Goods: A Lanchashire Consumer and Her Possessions, 1751-81', J. Brewer and R. Porter (eds.), Consumption and the World of Goods (London: Routledge, 1993), 274-301.

Wall, D., 'Family Meals and Evening Parties: Constructing Domesticity in Nineteenth-Century Middle-Class New York', in J. A. Delle, S. A. Mrozowski, and R. Paynter (eds.), Lines That Divide: Historical Archaeologies of Race, Class, and Gender (Knoxville, TE: University of Tennessee Press, 2000), 111-32.

Weatherill, L., 'The Meaning of Consumer Behavior in Late Seventeenth-and Early EighteenthCentury England', in J. Brewer and R. Porter (eds.), Consumption and the World of Goods (London: Routledge, 1993), 206-27.

Weinstein, B., 'Unskilled Worker, Skilled Housewife: Constructing the Working-Class Woman in Sao Paulo, Brazil', in J. French and D. James (eds.), The Gendered Worlds of Latin American Women Workers (Durham, NC: Duke University Press, 1997), 72-99.

Yates, S., Maid and Mistress: Feminine Solidarity and Class Difference in Five NineteenthCentury French Texts (New York, NY: Peter Lang, 1991).

Zulawski, A., 'Social Differentiation, Gender, and Ethnicity: Urban Indian Women in Colonial Bolivia, 1640-1725', Latin American Research Review, 25/2 (1990): 93-113. 